\title{
Isolation and Molecular identification of native As- resistant bacteria: As(III) and As(V) removal capacity and possible mechanism of detoxification
}

\section{Ulises Emiliano Rodriguez-Castrejón}

Universidad de Guanajuato Division de Ciencias Naturales y Exactas

Alma Hortensia Serafin-Muñoz ( $\sim$ sermuah@ugto.mx)

Universidad de Guanajuato https://orcid.org/0000-0003-3860-8508

\section{Aurelio Alvarez-Vargas}

Universidad de Guanajuato Division de Ciencias Naturales y Exactas

\section{Gustavo Cruz Jimenez}

Universidad de Guanajuato Division de Ciencias Naturales y Exactas

\section{Berenice Noriega-Luna}

Universidad de Guanajuato - Campus Leon

\section{Research Article}

Keywords: Rhodococcus gordoniae, Microbacterium hydrocarbonoxydans, Exiguobacterium indicum, Pseudomonas kribbensis, Xichu, Ars C, Aio, Arr.

Posted Date: June 15th, 2021

DOI: https://doi.org/10.21203/rs.3.rs-556252/v1

License: (a) (1) This work is licensed under a Creative Commons Attribution 4.0 International License. Read Full License

Version of Record: A version of this preprint was published at Archives of Microbiology on February 23rd, 2022. See the published version at https://doi.org/10.1007/s00203-022-02794-0. 


\section{Abstract}

The study of arsenic resistant microorganisms with high arsenic removal capacity is fundamental for the development of economically sustainable technologies for the treatment of water contaminated with this metalloid. In this work, the isolation and identification of 4 native strains was carried out.: Rhodococcus gordoniae, Microbacterium hydrocarbonoxydans, Exiguobacterium indicum and Pseudomonas kribbensis . R.gordoniae was identified as the bacterium with the highest growth capacity in both As(III) and As(V). E.indicum removed about $74.8 \%$ of Arsenate, $\mathrm{As}(\mathrm{V})$, and $61.7 \%$ of Arsenite , $\mathrm{As}(\mathrm{III})$, while R.gordoniae removed about $81.6 \%$ of $\mathrm{As}(\mathrm{III})$, and $77.2 \%$ of $\mathrm{As}(\mathrm{V})$, while that M.hydrocarbonoxydans was able to remove up to $79.9 \%$ of $\mathrm{As}(\mathrm{III})$ and $68.9 \%$ of $\mathrm{As}(\mathrm{V})$. Finally, it was observed that $\mathrm{P}$. kribbensis removed about $80.2 \%$ of $\mathrm{As}(\mathrm{V})$. This study also contributes to the possible detoxification mechanisms employed by these bacteria, the knowledge of which could be crucial in the successful implementation of in situ bioremediation programs.

\section{Introduction}

Arsenic (As) is a toxic metalloid present in high concentrations in natural waters due to various hydrogeological, geochemical conditions and anthropogenic processes, causing serious environmental health problems worldwide (Kumari et al., 2019). One of the main problems is the use of As-contaminated water from groundwater or river water for drinking or domestic use (Arroyo-Herrera et al., 2021; Muñoz et al., 2016; Osuna-Martínez et al., 2020). The main critical effects associated with long-term ingestion of inorganic arsenic by humans are cancer, skin lesions, cardiovascular disease, neurotoxicity, renal diabetes, and hematological and respiratory disorders (Cavalca et al., 2013). Although the World Health Organization recommends $10 \mu \mathrm{gL}^{-1}$ as the maximum concentration of As in drinking water as a permissible limit (World Health, 2018), several countries, including Mexico, India, and Bangladesh, continue to allow As from 25 to $50 \mathrm{\mu gL}^{-1}$ (Kumari et al., 2019; Loredo-Portales et al., 2017). Around the world, it is estimated that more than 40 million people are at risk of drinking water contaminated with As (Nordstrom, 2002). In Europe, the Pannonian Basin (Hungary, Serbia, and Romania), more than 600,000 residents are at risk of drinking water containing high As concentrations. In Asia, countries such as India, Bangladesh, China, Pakistan, and Vietnam, evidence high concentrations of As contamination. In Africa, elevated As concentrations have been reported in both the surface and groundwater (Mudzielwana et al., 2020). In Latin America, the estimated population at risk of As exposure exceeds 14 million people, with hundreds of recorded cases of exposure in countries such as Chile, Argentina, and Mexico (Castrejón et al., 2020; Muñoz et al., 2016; Osuna-Martínez et al., 2020). Within this context, in Mexico, it is estimated that approximately 450,000 people are regularly exposed to arsenic-contaminated water(Arroyo et al., 2013). For instance, in the Northeast of the State of Guanajuato high As levels have been detected in the municipality of the Xichu mining district (up to $62,302 \mathrm{\mu gg}^{-1}$ ), (Osuna-Martínez et al., 2020). The inorganic forms of As predominantly exist as trivalent arsenite $\left(\mathrm{As}(\mathrm{OH})_{3}, \mathrm{As}(\mathrm{OH})_{4}{ }^{-}, \mathrm{AsO}_{2} \mathrm{OH}_{2}{ }^{-}\right.$and $\left.\mathrm{AsO}_{3}{ }^{3-}\right)$ and pentavalent arsenate $\left(\mathrm{AsO}_{4}{ }^{3-}, \mathrm{HAsO}_{4}{ }^{2-}, \mathrm{H}_{2} \mathrm{AsO}_{4}{ }^{-}\right)$in natural waters. Pentavalent species of $A s, A s(V)$ are stable in oxygen rich aerobic environments, whereas the more soluble and toxic trivalent arsenite, $(\mathrm{As}(\mathrm{III}))$ is prevalent in moderately reducing anaerobic environments such as groundwater (Kumari et al., 2019; Prasad et al., 2011). As(III) is 70 times more toxic than methylated species and 10 times more toxic than $\mathrm{As}(\mathrm{V})$, which is poorly soluble in water and therefore less bioavailable. As(III) interacting with thiol groups of proteins and enzymes inhibiting their functions, is able to adhere to the surface of various minerals, such as ferrihydrite and alumina (Cavalca et al., 2013). Existing technologies for As removal are primarily based on physico-chemical methods such as precipitation and/or adsorption of As in the form of As(V), 
lime softening, ion exchange, and membrane separation. Most of these methods involve the chemical preoxidation of $\mathrm{As}(\mathrm{III})$ to $\mathrm{As}(\mathrm{V})$, as the negatively charged arsenate adsorbs easily to solid surfaces, thereby facilitating precipitation and removal from contaminated matric. However, this may result in the production of undesirable by-products in such a way as to generate environmentally unfriendly technologies, in addition to the fact that they may be costly to apply. Bioremediation technique, which involves the use of microbes to detoxify toxic heavy metals or metalloids, has been receiving increasing attention in recent times as a means of cleaning up a polluted environment. Biosorption of metal ions is an example of a wide variety of potential and actual applications of the bioremediation technique in polluted water treatments (Pandey \& Bhatt, 2016b). The use of microorganisms for the biosorption of As ions from water is an extremely efficient process. Bioaccumulation can also be considered as a second part of the process of metal and/or metalloid sequestration by living biomass (Kumari et al., 2019). In a geographical context, native bacteria inhabit contaminated areas. These possess the innate ability to tolerate high concentrations of As by the process of extrusion after microbial oxidation, reduction and methylation, collectively termed as biotransformation processes. Microbial transformation of $A s(I I I)$ to $A s(V)$ is an environment-friendly and economically viable alternative to the aforementioned treatment methods (Anna Corsini et al., 2014; Kumari et al., 2019). On the other hand, in bacteria, the genes involved in As metabolism include the ars (arsenic resistance system), aox (arsenite oxidase) and arr (arsenate respiratory reduction) operons, which can be found in both plasmids and chromosomes. Tolerance or transformation mechanisms in some bacteria include a chromosomal or plasmid coded ars operon with three or five genes. The operon includes a regulatory gene (arsR), a coding gene for a transmembrane ejection pump specific for arsenite (arsB), and a coding gene for an arsenate reductase (arsC) where the reduction from $\mathrm{As}(\mathrm{V})$ to As(III) is carried out by the same gene (Kruger et al., 2013). The arroperon includes arrA and arrB genes, in dissimilatory As(V)-reducing bacteria these genes are sometimes flanked by ars genes, forming clusters of arsenic-metabolizing genes in their genomes (arsenic-metabolizing gene island) (Tsuchiya et al., 2019). The objective of the present work was to analyze the resistance, growth and removal capacity of $\mathrm{As}(\mathrm{III})$ and $\mathrm{As}(\mathrm{V})$ by four native strains. These species were isolated, molecularly identified, and their genes (arsenic oxidizers and reducers) were amplified to propose a possible mechanism of detoxification against As. It is worth mentioning that this work is the first to investigate the As removal capacity of two little studied strains $P$. kribbensis and $M$. hydrocarbonoxydans, as well as their possible detoxification mechanism properties.

\section{Materials And Methods}

2.1 Study area and sampling. Water samples were collected along the Xichu River, within the mining area "La Aurora" corresponding to the municipality of Xichu, Gto, Mexico. The location points were AJ $\left(21^{\circ} 19^{\prime} 40.04\right.$

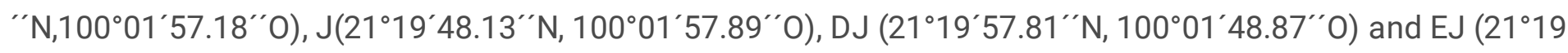
$\left.52.88^{\prime \prime} \mathrm{N}, 100^{\circ} 01^{\prime} 54.09^{\prime \prime} \mathrm{O}\right)$, Figure 1. For microbiological sampling sterilized Falcon tubes were used. Each one was introduced into the body of water until it was filled and sealed before being removed from the body of water. At the same time, water samples for the physicochemical characterization were collected. For water sampling, the NMX-AA-14-1980 standard was taken into consideration. The plastic bottles used were first treated with $\mathrm{HNO}_{3}$ $10 \%$ for $48 \mathrm{~h}$ and washed with bi-distilled water. All samples were stored and kept under refrigeration until arrival at the laboratory.

\subsection{Analysis of the water samples}


2.2.1 Physico-chemical characterization. Samples were analyzed in situ according to the parameters established in the NOM-127-SSA1-2017. The quantifications of $\mathrm{Fe}^{2+}, \mathrm{S}^{2-}, \mathrm{SO}^{4-}, \mathrm{NO}_{3}{ }^{-1}, \mathrm{~K}^{+}, \mathrm{Mg}^{2+}, \mathrm{Mn}^{2+}$ and $\mathrm{Zn}^{2+}$ were done by handheld colorimeter (HACH DR $900 \AA$, USA). Temperature $\left({ }^{\circ} \mathrm{C}\right), \mathrm{C} . \mathrm{E}\left(\mu \mathrm{Scm}^{-1}\right)$ and dissolved oxygen (O.D), were quantified by water analysis potentiometer, (Thermo scientific $\AA$, USA). The determination of total As was carried out by atomic absorption spectrometry.

2.2.2 Determination of total As concentration. All samples were digested with concentrated $\mathrm{HNO}_{3}\left(\mathrm{Nitric}_{\text {acid }} 70 \%\right.$, purified by redistillation, $\geq 99.999 \%$ trace metals basis, Sigma Aldrich, USA) following the USEPA 3015A method (Microwave Assisted Acid Digestion of Aqueous Samples, USEPA North American Environmental Protection Agency), (Element, 2007). A microwave digestion system Titan MPS 8 Position Microwave Sample Preparation System MPS ${ }^{\text {TM }}$ (model N3130110, Perkin Elmer, USA) was used. Deionized water (18.2 $\mathrm{MWcm}^{-1}$, resistivity) was used for all dilutions, obtained in a purification system (Milli-Q® direct 8/16 system, France). The flasks and all the material used in the preparation of the solutions were carefully cleaned in $15 \% \mathrm{HNO}_{3}$ for $48 \mathrm{~h}$, rinsed in deionized water and dried in laminar flow. Quality control for the determination of metals was carried out by analysis of the standard reference materials (SRM), LGC6027 (Trace Elements in water). The calibration curve was established using the standard solutions prepared in $1 \mathrm{~mol} \mathrm{~L}^{-1} \mathrm{HNO}_{3}$ by dilution from stock solutions (As Standard for AAS, TraceCERT ${ }^{\circledR}, 1000 \mathrm{mg} / \mathrm{L}$ As in nitric acid, USA). A PerkinElmer PinAAcle 900T Atomic Absorption Spectrometer equipped with MHS-15 Mercury/Hydride System (HG-AAS) was used in this study. Highpurity argon (99.999\%) was used as carrier gas (at a flow rate of $300 \mathrm{~mL} / \mathrm{min}$ ) as well as shielding gas (at flow rate of $700 \mathrm{~mL} / \mathrm{min}$ ). A hollow cathode lamp operating at $18 \mathrm{~mA}$ was used and a spectral bandwidth of $0.7 \mathrm{~nm}$ was selected to isolate the $193.7 \mathrm{~nm}$ As line. Peak height was used for quantitation. The detection limit (LOD) was calculated from the standard deviations of the blank solution (mostly nitric acid $0.2 \%$ of $\mathrm{HNO}_{3}$ ), using the criterion of three times the standard deviations and ten times the standard deviations, respectively. All analyses were performed in the Environmental Engineering Laboratory of Sustainable Innovation of the UG-Guanajuato Campus (clean room, class 1000).

2.3 Isolation of strains in selective media with As. Nutritional Agar (NA) (BIOXON®, Mexico) was prepared with arsenate from sodium arsenate, $\mathrm{Na}_{3} \mathrm{AsO}_{4}$, (Sigma Aldrich-Merck, USA) and arsenite from sodium arsenite, $\mathrm{NaAsO}_{2}$, (Sigma Aldrich-Merck, USA). The media were adjusted to pH 8.5 by adding $0.1 \mathrm{M} \mathrm{NaOH}$ (Fisher Scientific, USA) since it was the value quantified between the water samples at the sampling points. A $100 \mu$ l of water sample was inoculated to NA plates containing $3.5 \mathrm{mM}$ of $\mathrm{As}(\mathrm{III})$ and $\mathrm{As}(\mathrm{V})$ respectively; the spread plate method was used to obtain single colonies. The plates were incubated under aerobic conditions at $30^{\circ} \mathrm{C}$ (Aguilar et al., 2020; Kumari et al., 2019). For sterilization of the media and the As salts solution, an autoclave (LAB-MED® model LMGV1M, Mexico) was used. Bacterial colonies with different forms, color and margins were purified on solid medium containing As at the same concentration, at least 3 times and stored at $-80^{\circ} \mathrm{C}$ in a solution of $30 \%$ glycerol. The strains were characterized according to morphological characteristics: shape, margin, chromogenesis, optical detail and surface with the help of an optical microscope (Primo Star Zeiss GmbH, Germany). 3dp.rocks/lithophane software was used for image enlargement and analysis. Gram staining was performed with a Gram staining set (Millipore Sigma; cat REF 77730, USA) according to standard procedures (Gerhardt et al., 1994). Subsequently, from the isolated strains, one strain from each site was selected for the following analyses. 
2.4 Molecular identification of As resistant isolates. The extraction of the genomic DNA of the bacteria was carried out, based on the protocol described by Murray and Thompson (Murray \& Thompson, 1980), where the technique of extraction with Cetyl Trimethyl Ammonium Bromide (CTAB)/ $\mathrm{NaCl}$ was used. Once the extraction was finished, electrophoresis was performed in a $1 \%$ agarose gel, stained with ethidium bromide to check the quality and concentration of the DNAg. All the reagents used were from the commercial company Sigma Aldrich-Merck.

2.4.1 Amplification procedure. Several concentrations of nucleic acid extracts were suspended in $5 \mu l$ portions of water. These DNA dilutions were added in a PCR mix containing: $2.5 \mu$ of 10X PCR buffer, $2 \mu$ l of direct and reverse initiators, Midex D and Midex R respectively, (final concentration, $1 \mu \mathrm{M}$ each), $0.5 \mu$ l of deoxynucleoside triphosphates (dNTPs) (final concentration, $200 \mu \mathrm{M}$ ), $2.0 \mu \mathrm{l}$ of $\mathrm{MgCl}_{2}$ (final concentration $2.0 \mathrm{mM}$ ), and $3.0 \mathrm{U}$ of Taq polymerase (Invitrogene ${ }^{\circledR}$ ). Water Milli-Q ${ }^{\circledR}$ was added, giving a final volume of $25 \mu l$ (Saiki, 1990). The mixture was placed in a thermal cycler (Multigene LabNet ${ }^{\circledR}$ ), with the following PCR conditions: initial denaturation at $95^{\circ} \mathrm{C}$ for $3 \mathrm{~min}, 30$ cycles of $95^{\circ} \mathrm{C}$ for $30 \mathrm{~s}, 59^{\circ} \mathrm{C}$ for $30 \mathrm{~s}$ and $72^{\circ} \mathrm{C}$ for $3 \mathrm{~min}$, followed by a final extension at $72{ }^{\circ} \mathrm{C}$ for $5 \mathrm{~min}$ (45). The purification of the PCR products was carried out with GE Healthcare ${ }^{\circledR}$ kit: GFX PCR DNA and Gel Band Purification, in which protocols and supplier suggestions were followed. Then, the purified PCR products were sequenced at the National Laboratory of Agricultural, Medical and Environmental Biotechnology (IPICYT), Mexico. Finally, the sequences were compared to those in the National Biotechnology Information Center (NCBI) database (Sayers, Beck, et al., 2021), using the BLASTn algorithm (the basic local alignment search tool).

2.4.2 Phylogenetic analysis. To obtain the most similar sequences of validly named bacteria, the $16 \mathrm{~S}$ rRNA gene sequences of strains were compared with the available 16S rRNA gene sequences via a BLASTN 2.10.1 search. This is a program for comparing nucleotide sequences of DNA and/or RNA (Schwartz et al., 2000). This application is available on the NCBI website. A phylogenetic tree schematically reflects the degree of genetic kinship between bacteria based on their $16 \mathrm{~S}$ ribosomal genes in order to obtain the correct sequence of each one of the ribosomal genes analyzed. The evaluation of the electropherograms and the alignment of the direct chain with the reverse was carried out. Multiple alignments of the sequences of the strain with other bacterial species were carried out, using the CLUSTAL X program (Larkin et al., 2007). The 16S rDNA phylogenetic tree was constructed using the distance method Neighbor-Joining (Saitou \& Nei, 1987), that relates bacterial sequences from references selected in GenBank® (Sayers, Cavanaugh, et al., 2021).

2.5 Minimum inhibitory concentration of the isolated. The As(III) and $\mathrm{As}(\mathrm{V})$ resistance of the selected isolates was evaluated using minimum inhibitory concentration tests under aerobic conditions. The minimum inhibitory concentration (MIC) is defined as the lowest concentration of both inorganic As species that completely inhibits growth. MIC for four bacterial cultures were determined in nutrient broth medium (NB) (BIOXON®, Mexico) containing different concentrations of $\mathrm{As}(\mathrm{III})$ and $\mathrm{As}(\mathrm{V})$, which ranged from 1 to $20 \mathrm{mM}$ (Kumari et al., 2019). The medium was inoculated with cell suspensions taken from fresh cultures in the log phase and incubated at 120 rpm in an incubation shaker (Thermo Scientific MaxQ 4000, USA), at $30^{\circ} \mathrm{C}$ for $96 \mathrm{~h}$. Two controls were prepared, for each experiment with $\mathrm{As}(\mathrm{III})$ and with $\mathrm{As}(\mathrm{V})$ : (i) Nutrient broth supplemented with only bacteria (without arsenite or arsenate) (ii) Nutrient broth with arsenite or arsenate, and without bacteria. Optical density of cell cultures was taken at $24 \mathrm{~h}$ intervals for $96 \mathrm{~h}$ for determining the bacterial growth responses at different concentrations of $\mathrm{As}(\mathrm{III})$ and $\mathrm{As}(\mathrm{V})$. Bacterial growth was measured by determining the optical density at $600 \mathrm{~nm}$ $\left(\mathrm{OD}_{600}\right)$ in a Uv-vis Spectrophotometer (DR 3900, $\left.\mathrm{HACH}, \mathrm{USA}\right)$. Each experimental set up was prepared in triplicate. 
2.6 Effect of pH on the growth bacteria culture. Yeast Extract Mannitol (YEM) broth (Merck, Germany) was prepared. The $\mathrm{pH}$ was adjusted from 3.5 to 12 by adding $0.1 \mathrm{M} \mathrm{HCl}$ or $\mathrm{NaOH}$ (Fisher Scientific, USA), and measured with a pH meter (Thermo Scientific Orion 4-Star, USA). It was then autoclaved at $121^{\circ} \mathrm{C}$ for 20 minutes. The isolated strains were inoculated onto the medium and cultured at $30{ }^{\circ} \mathrm{C}$ in $250 \mathrm{~mL}$ Erlenmeyer flasks shaken at $120 \mathrm{rpm}$. Bacterial growth was measured by determining $\mathrm{OD}_{600}$ after a $24 \mathrm{~h}$ growth period.

2.7 Gene expression analysis. The presence of the arr (respiratory arsenate reduction system) and aox (respiratory arsenite oxidation system) genes was detected through their amplification using the DNA of the isolated bacterial strains (Chang et al., 2010). PCR amplification was performed with primers: arrA-CVF1 and arrACVR1 (direct and reverse respectively) for arsenate reductase A. As an initial step these primers were tested and evaluated in silico for virtual amplification of arrA genes in clones and subsequently for amplification and sequencing of arrA genes from groundwater samples as the monitoring of the arrA gene can provide useful information about the variations of the arsenate-reducing microbial species. The samples were then amplified with the primers: aoxA and aoxB (direct and reverse respectively) for arsenite oxidase $A B$. The primer " $a$ " (5'AATGACACCTTCACGGCG-3'), annealing 48 bp upstream of the aoxA stop codon, and primer "b" (5'AGCACTCGATCTTTTGCAG-3'), annealing 872 bp downstream of the aoxB start codon, The amplification program was set to the following conditions: $94^{\circ} \mathrm{C}$ (initial denaturation temperature) for 3 minutes ( $1 \mathrm{cycle}$ ). The temperature was then cycled to $94^{\circ} \mathrm{C}$ for $30 \mathrm{sec}$., to $60^{\circ} \mathrm{C}$ for $40 \mathrm{sec}$., and then to $72^{\circ} \mathrm{C}$ for $1 \mathrm{~min}$. This process was repeated for an additional 30 cycles, followed by a final extension at $72{ }^{\circ} \mathrm{C}$ for $10 \mathrm{~min}$. Finally, the amplification of the genes was verified in a 1\% agarose gel stained with ethidium bromide (Mirza et al., 2017).

\subsection{Comparison of the growth profile among the four bacteria under $\mathrm{As}(\mathrm{III})$ and $\mathrm{As}(\mathrm{V})$ stress. The assays for} growth kinetics were designed using a factorial design " $A{ }^{\star} B$ " of two-factor 8x4 (time and strain), where the " $A$ " factor has eight levels (0-168 hours) and the "B" factor has four levels (A1, S3, A4, A11) respectively. The above was intended to identify the main effects of strains and time on microbial growth in the presence of As(III) and $\mathrm{As}(\mathrm{V})$. Growth kinetics were planned in $30 \mathrm{ml}$ of YEM broth, with an aliquot of each culture being taken every 24 hours. Three experiments were carried out as follows: 1) Growth kinetics without As, 2) Growth kinetics in YEM with As(III) and, 3) Growth kinetics in YEM with As(V). The concentration of arsenic was defined according to the result obtained by the MIC. Incubation conditions in Falcon tubes were inoculated with fresh bacteria culture at $30^{\circ} \mathrm{C}$ at $120 \mathrm{rpm}$ for $168 \mathrm{~h}$. Absorbance was measured at $600 \mathrm{~nm}$ in a Uv-vis Spectrophotometer (DR 3900, Hach, USA).

2.8.1 Statistical analysis. Initially, the determination of Normality (Shapiro-wilk test), Homogeneity (Bartlett test) and independence (Durbin Watson test) of the data obtained was carried out (Kirchman et al., 1982). The experiments in this study were performed in triplicate $(n=3)$. The values of the Growth kinetics are given as means+-S.D using Microsoft excel software, version 2010. Data obtained from the factorial design were analyzed by a two-way analysis of the variance test (ANOVA) to identify statistically significant differences in the growth of bacteria in the presence of $\mathrm{As}(\mathrm{III})$ and $\mathrm{As}(\mathrm{V})$. Tukey's multiple range test was performed to identify the strains with the highest potential for interaction with $\mathrm{As}(\mathrm{III})$ and $\mathrm{As}(\mathrm{V})$, as well as their optimal growth times. Significance of differences was defined as $P<0.05$, with a 95\% confidence interval, using Minitab software, version 19.

2.9. Removal of $A s(I I I)$ and $A s(V)$ by isolated strains. Isolated strains that showed the best growth in the presence of As were selected and cultured under aerobic conditions. The concentration of As used was in relation to the 
result obtained by the MIC. Synthetic water was prepared from the analyzed constituents of the water samples from the studied site based on the average concentrations of the results obtained (section 2.2.1), All the reagents used were from Sigma Aldrich. Bacterial pellet was collected and lyophilized as described (Kao et al., 2013): Biosorption assays for $\mathrm{As}(\mathrm{III})$ and $\mathrm{As}(\mathrm{V})$ were performed using the lyophilized cell pellet of the selected strains. From each strain, the lyophilized cell pellet $(5 \mathrm{~g} / \mathrm{l})$ was added to $125 \mathrm{ml}$ Erlenmeyer flasks with $30 \mathrm{ml}$ of culture medium containing As(III), pH was adjusted to 8.5 by adding dilute solutions of $\mathrm{NaOH}$, while the contact time was 168 minutes. The flasks were shaken $(120 \mathrm{rpm} / \mathrm{min})$ at $30^{\circ} \mathrm{C}$. Samples were withdrawn every $24 \mathrm{~h}$ and centrifuged at $4000 \mathrm{rpm}$ at $4^{\circ} \mathrm{C}$ for $15 \mathrm{~min}$. In parallel, the same procedure was performed for the case of As(V). The supernatants were analyzed to determine the concentrations of $\mathrm{As}(\mathrm{III})$ and $\mathrm{As}(\mathrm{V})$ by the methodology described in section 2.9.1. All experiments were conducted in triplicate. The removal of As(III) and As(V) in percentages was calculated by using Eq. (1), (Kumari et al., 2019).

Bioremoval As(III) or As(V) $\%=\frac{\text { Ci-Cf }}{\mathrm{Ci}} \times 100$

where,

Ci - Initial concentration of As(III) or As(V)

Cf - Final concentration of As(III) or As(V)

2.9.1 Analytical method. The determination of As levels was performed by HG-AAS described in section 2.2. The methodology carried out for the determination of $\mathrm{As}(\mathrm{III})$ and $\mathrm{As}(\mathrm{V})$ was by the combination of coprecipitation and atomic absorption spectrometry by hydride generation, as described in a previous work (Tuzen et al., 2009). As(V) was quantitatively recovered on aluminum hydroxide precipitate. After the oxidation of As(III) by using dilute KMnO4 (Sigma Aldrich-Merck, USA), the developed coprecipitation was applied to determine total As. As(III) was calculated as the difference between the total As content and $\mathrm{As}(\mathrm{V})$ content. The limits of detection (LOD) were based on three times the blank sigma $(n=20)$. The same certified reference materials were used for method validation as described in section 2.2.2.

2.10 Analysis of Possible mechanism of biological removal of Arsenic. A bioinformatic search of the genes of the isolated species was carried out from the databases of the National Center for Biotechnology Information (NCBI).This platform includes the database (BD) Public library called GenBank® , which contains an extensive collection of nucleotide sequences obtained from more than 300,000 species, (Sayers, Cavanaugh, et al., 2021).

\section{Results And Discussion}

3.1 Physicochemical characterization and determination of total As in water samples. The results of the water characterization are shown below in Table 1. The average $\mathrm{pH}$ value obtained in the water samples was 8.73 \pm 0.52 , which shows that within the sampling region in the area of the "La Aurora" mine, a highly alkaline medium predominates. The average values for the parameters of C.E, O.D and temperature were $725.25 \pm 155.06 \mu \mathrm{Scm}^{-1}$, $4.75 \pm 0.66 \mathrm{mgL}^{-1}$ and $28.73 \pm 0.96^{\circ} \mathrm{C}$, respectively. For $\mathrm{K}^{+}, \mathrm{Mg}^{2+}, \mathrm{Mn}^{2+}, \mathrm{Fe}^{2+}, \mathrm{Zn}, \mathrm{SO}_{4}{ }^{2-}, \mathrm{NO}_{3}{ }^{-}$were $1.97 \pm 0.67$, $33.55 \pm 3.17,0.20 \pm 0.16,0.05 \pm 0.02,0.03 \pm 0.01,136.88 \pm 21.15$ and $4.64 \pm 4.27 \mathrm{mgL}^{-1}$, respectively. Table 2 
shows the As values found in the water samples from the four sampling points (AJ, EJ, J, and DJ). The analytical parameters obtained by the HG-AAS method are shown at the bottom of the table. The mean As concentration was $58.48 \pm 33.68 \mathrm{\mu gL}^{-1}$, with the maximum value being $108 \pm 2.1 \mu \mathrm{gL}^{-1}$ (DJ) and the minimum $35 \pm 0.2 \mu \mathrm{gL}^{-1}$ (AJ). This heterogeneity in element concentration in different samples is common in mining areas due to constant movement and excavation of materials being mined (Ono et al., 2016). The values of As concentrations found in all water samples are above the maximum permissible limit of both the World Health Organization, WHO $\left(10 \mu \mathrm{gL}^{-1}\right)$ and by the Mexican Norm, NOM-127-SSA1 $\left(25 \mu \mathrm{gL}^{-1}\right)$ (Monterrey; World Health, 2018). In this study area, the range of As concentration reported in water samples ranges from 98 to $163 \mu \mathrm{gL}^{-1}$ (Loredo-Portales et al., 2017; Muñoz et al., 2016; Rodríguez et al., 2019). It should be noted that few studies have reported on the quantification of As in surface water from the Xichu area. Most studies focus on soil, sediment, and rock samples (Osuna-Martínez et al., 2020). It is important to mention that the main sources of water in this region are the river, streams and groundwater. Approximately $100 \mathrm{~m}$ from the mining area there are some active corn fields where this water is used for irrigation (Loredo-Portales et al., 2017), in addition to being used for domestic consumption.

3.2 Morphology and molecular identification of isolated strains. From the strains obtained, a total of 4 morphologically distinct bacteria capable of growing on As(III) and As(V) were selected (one from each sampling point) and isolated. The strains were named A1AJ, A1J, A4DJ and S3EJ. Figure 2 shows the morphological characteristics of the isolated strains. A1AJ, A1J and A4DJ were gram positive while S3EJ was gram-negative. For A1AJ, the colonies were yellow and rod-shaped. A1J presented a light pinkish-red color with a coccoidal ovoid shape. A4DJ had an orange color and a stick shape. In the case of S3-EJ, the colonies were circular, convex, mucoid and translucent beige. All strains were aerobic.

Figure 3 shows the phylogenetic tree of the 16S rRNA gene, where the relationship of the isolates is observed with support from the NIH genetic sequence database, GenBank ${ }^{\circledR}$ (Sayers, Cavanaugh, et al., 2021). Analysis of 16S rRNA sequence showed that A1J belongs to the Rhodococcus gordoniae W4937 ${ }^{\top}$ (99.34\% identity) (Jones et al., 2004). The strain S3EJ showed $99.23 \%$ similarities with the Pseudomonas kribbensis $46-2^{\top}$ (D. H. Chang et al., 2016). The strain A4DJ showed $100 \%$ similarities with several Exiguobacterium, but according to the phenotypic characteristics can presumably be identified as the Exiguobacterium indicum $\mathrm{HHS} 31^{\top}$ (Chaturvedi \& Shivaji, 2006). The strain A1AJ showed 99.78\% similarities with the Microbacterium hydrocarbonoxydans NBRC 103074

${ }^{\top}$ (Schippers et al., 2005). The summary of the molecular identification of the isolates is represented in Table 3 . In this same context, based on the morphology observed in this study for each strain, there is an agreement with the resulted cited in other works (D.-H. Chang et al., 2016; Jones et al., 2004). It should be noted, that for the first time the molecular identification of native bacterial strains in this geographic region has been reported.

3.3 Minimum inhibitory concentration of the isolated. The As tolerance of the four bacterial cultures was tested by determining their minimum inhibitory concentration (MIC). The percentage analysis was in relation to the growth of the control group. The $R$. gordoniae, E. indicum and $M$. hydrocarbonoxydans were able to grow in $96 \mathrm{~h}$ under control conditions (absence of As) and in As up to $10 \mathrm{mM}$, both in media with arsenite (93.1 $\pm 7.2 \%)$ and arsenate $(95.2 \pm 4.4 \%)$. However, for the case of R.gordoniae in $12 \mathrm{mM}$ a slight growth of $32.5 \%$ (As (III) and $39.8 \%$ (As (V)) was observed. For E.indicum and M.hydrocarbonoxydans average growth rates were of $4.3 \pm 0.8$ $\%$ and $9.9 \pm 3.1 \%$ in cell growth was observed in $12 \mathrm{mM} \mathrm{As}(\mathrm{III})$ and $\mathrm{As}(\mathrm{V})$ respectively. P. kribbensis presented a MIC of $5 \mathrm{mM}(69.7 \%)$ for $\mathrm{As}(\mathrm{III})$, and $10 \mathrm{mM}$ (88.4\%) for $\mathrm{As}(\mathrm{V})$. The genus of these species has previously been 
reported to be highly resistant to As (Kumari et al., 2019; Pandey \& Bhatt, 2015). However, there are few related studies for $R$. gordoniae, E. indicum, M. hydrocarbonoxydans and P. kribbensis, specifically.

3.4 Effect of $\mathrm{pH}$ on the growth bacteria culture. The $\mathrm{pH}$ of the surrounding medium plays a critical role in determining As mobilization and toxicity and influences the occurrence and distribution of the microorganisms themselves. In microbial systems, $\mathrm{pH}$ controls the energy yields of redox reactions common in anoxic environments, including syntrophic oxidation, iron reduction, sulfate reduction, and methanogenesis(Cavalca et al., 2013). Figure 4 shows the results of the effect of $\mathrm{pH}$ on the growth of the four bacterial cultures. All bacterial cultures showed growth between $\mathrm{pH} 5.5$ and 10. Very poor growth was observed within the pH range of 4.0 to 5.5 . At acidic $\mathrm{pH}<4$, no growth was observed. The maximum $\mathrm{OD}_{600}$ value occurred for $R$. gordoniae, followed by $M$. hydrocarbonoxydans, P. kribbensis and E, indicum, at $\mathrm{pH}$ 8.5, 8.0, 7.5 and 7.5, respectively. Results from the present study are consistent with earlier reports where As-resistant bacteria were found to grow in wide range of pH 5-10 (Kumari et al., 2019) but were unable to tolerate extreme conditions, i.e. pH 2 or pH 11.

3.5. Gene expression analysis. In this work the presence of Aio genes encoding Aio enzyme (arsenite oxidase) by PCR was detected in: M.hydrocarbonoxydans, P.kribbensis, E.indicum, but not in R. gordoniae, Table 4. As with the results of previous work, the Rhodococcus strain failed to give positive amplification, probably due to mismatches between the tested primers and the gene sequence (Anna Corsini et al., 2014). However, it presented a significantly higher growth in terms of biomass generation and growth rate. The above suggests that $R$. gordoniae could metabolize arsenic in a chemoautotrophic manner. Previous studies have shown that species of the phylum Actinobacteria, Firmicutes, and Proteobacteria are distinguished by their ability to interact with inorganic arsenic (Hamood Altowayti et al., 2020). The genus Rhocodccoccus is reported with the presence of mostly reducing genes, but also the presence of As(III)-oxidizing genes (Kumari et al., 2019; Prasad et al., 2011; Wang et al., 2020). The determination of the presence of resistance-conferring genes is influenced by the environmental conditions to which they are exposed (Wang et al., 2020). On the other hand, the presence of arsenic in water serves as a selection of microorganisms and at the same time enriches their growth due to the presence of this operon. One example is that, in conditions with high sulfate-reduction activity, genes such as aio $A$ and $a o x B$ enriched by oxic environments are inhibited by this activity. In accordance with previous results (A. Corsini et al., 2014), these data corroborate the hypothesis that the ars operon could be slightly different even though the strains are categorized in the same genera, supporting the hypothesis of a horizontal transfer of the arsenic genes within bacterial population.

3.6 Comparison of the growth profile among the four bacteria under $\mathrm{As}(\mathrm{III})$ and $\mathrm{As}(\mathrm{V})$ stress. The growth patterns for R. gordoniae, M. hydrocarbonoxydans, E. indicum and P. kribbensis under arsenite and arsenate stress are shown in Figure 5. Based on the results obtained in the MIC, the As concentration used for this study was $10 \mathrm{mM}$ for both $\mathrm{As}(\mathrm{III})$ and $\mathrm{As}(\mathrm{V})$. The assays were designed through the 8x4 factorial design, to evaluate the effect of strains and time on bacterial growth in the presence of $\mathrm{As}(\mathrm{III})$ and $\mathrm{As}(\mathrm{V})$. A value of $\mathrm{p}<0.05$ was obtained for strain-time interactions, with an effect on their growth in the presence of As(V) and As(III). By means of Tukey's multiple comparisons analysis, the optimal growth times of the isolates in the presence of both inorganic As species and the significant differences in their behavior were identified, as well as the selection of the bacterial strains with the greatest capacity for interaction with As. $R$. gordoniae $(R . g)$ was shown to be the strain with the highest growth capacity in the presence of $\mathrm{As}(\mathrm{III})$ and $\mathrm{As}(\mathrm{V})$, presenting a statistically higher growth compared to the other strains under study, its optimal growth times (exponential phase) being $144 \mathrm{~h}$ for $\mathrm{As}(\mathrm{V})$ and $\mathrm{As}(\mathrm{III})$. On the other hand, strain M. hydrocarbonoxydans (M.h) showed good growth although significantly $(P<0.05)$ lower 
than $R . g$ for both $\mathrm{As}(\mathrm{III})$ and $\mathrm{As}(\mathrm{V})$. M.h showed constant growth up to $168 \mathrm{~h}$ in the case of $\mathrm{As}(\mathrm{V})$, while in the presence of As(III) the exponential phase occurred at up to $120 \mathrm{~h}$. In the presence of As III, an interesting phenomenon was observed at 120-168 h by M. hydrocarboxydans. It showed a biphasic behavior, similar to a diauxic growth. Possibly due to the fact that within its detoxification mechanism, M.h presents an adaptive mechanism. As(III) as a stressful stimulus, it activates an adaptive response that increases the resistance of the bacterium to a higher level of stress. This response may involve the expression of genes encoding cytoprotective proteins, such as chaperones, heat shock proteins, antioxidant enzymes and growth factors. On the other hand, $E$. indicum (E.I) showed growth capacity in the presence of As(III) and As(V). However, its behavior is different; while in the presence of $\mathrm{As}(\mathrm{III})$ it presents significant $(\mathrm{P}<0.05)$ and continuous growth up to $96 \mathrm{~h}$ while in the presence of $\mathrm{As}(\mathrm{V})$ it presents exponential growth in $24 \mathrm{~h}$ and enters a stationary phase from 24 to $168 \mathrm{~h}$ without significant differences $(p \geq 0.05)$. For $P$. kribbensis $(P . k)$, an effect on its growth was identified through interaction with $A s(V)$, reaching a maximum growth in $168 \mathrm{~h}$, which in turn is statistically equal to $M$. $h$, while in the presence of As(III), it is completely inhibited. The growth of the isolates in the presence of $A s(I I I)$ and $A s(V)$ was presented as follows: from the highest growth capacity to the lowest, according to the Tukey test: a) As(III); R.g>M. $h>E . i>P . k$, and, b) As $(V) ; R . g>M . h=P . k>E$. $i$. For the cases mentioned $R . g$ presents statistically higher growth in comparison with the other isolates under study after $24 \mathrm{~h}$ interaction, being the bacterium with the highest growth capacity with As(III) and $\mathrm{As}(\mathrm{V})$, and also at a higher rate. M.h presents good growth in the presence of As(III), with a metabolism probably differing from $R . g$ because it is higher. M.h reached its optimum growth at $144 \mathrm{~h}$, while for this average $R$. $g$ reached it after $48 \mathrm{~h}$. As reported in other previous works, the duration of the lag phase gradually increased as the As(III) concentration in the medium was increased, and as mentioned above this could be due to the fact that with increasing As(III) concentration, an adaptive phase was required to tide over high toxicity of As(III), (Kumari et al., 2019). In the presence of As(V), the correlation coefficient values for a $168 \mathrm{~h}$ growth period for R.g, M.h, E. i and P. k were -0.9935, -0.9792, -0.5884 and-0.9932, respectively. While in As(III) for R.g, M.h, and E.i they were $-0.9966,-0.9911$ and -0.9636 , respectively. Negative values suggest that As stress has an inversely proportional effect on the growth of the bacteria (Kumari et al., 2019).

\subsection{Removal of $\mathrm{As}(\mathrm{III})$ and $\mathrm{As}(\mathrm{V})$ by isolated strains. As in the previous section, the concentration of As in the} medium was based on the result of the MIC, (10 mM was used for As(III) and As(V)). Based on the above results, in the case of $P$. kribbensis, it was analyzed for $\mathrm{As}(\mathrm{V})$ only. The $\mathrm{pH}$ used was 8.5 since this is the average $\mathrm{pH}$ present in the contaminated area of study. Maximum As-removal occurred during the initial growth phase, between $24 \mathrm{~h}$ (E. indicum), $48 \mathrm{~h}$ ( $R$. gordoniae and M.hydrocarbonoxydans) and $72 \mathrm{~h}$ ( $P$. kribbensis). In the same context, the concentrations were $2.52 \mathrm{mM}$ (E. indicum), $3.19 \mathrm{mM}$ (M.hydrocarbonoxydans) and $4.03 \mathrm{mM}(R$. gordoniae) for As(III) and $3.09 \mathrm{mM}$ (R. gordoniae), $3.33 \mathrm{mM}$ (M.hydrocarbonoxydans), 5.21mM (E. indicum) and $2.57 \mathrm{mM}$ ( $P$. kribbensis) for As $(\mathrm{V})$. The results of this study revealed different behaviors between the percentages of $\mathrm{As}(\mathrm{III})$ and $\mathrm{As}(\mathrm{V})$ removal by isolated strains, Figure 6. In the case of $E$. indicum, it was more efficient in the removal of $\mathrm{As}(\mathrm{V})$ than $\mathrm{As}(\mathrm{III})$. At the end of the experiment (168 h), E.indicum successfully removed approximately $74.83 \pm 1.2 \%$ of $A s(V)$ from the medium, while only $61.77 \pm 0.8 \%$ removal was achieved in the case of As(III), Figure 6(a). For this genus, as in previous studies, removal percentages of $99 \%$ for As (V) and $90 \%-99 \%$ for As (III) (Pandey \& Bhatt, 2016a, 2016b) have been reported, depending on the method developed, Table 5. Bacteria of the genus Exiguobacterium are adapted to use multiple strategies that allow them to maintain themselves under the stress conditions they face in their environments, namely the high toxicity generated by As (Andreasen et al., 2018). For this, bacteria use a large arsenal of proteins related to protein synthesis, detoxification, energy generation, transport and global stress (Pandey \& Bhatt, 2015). The differences between the 
level of resistance exhibited by the isolated strains and the reported strains may have resulted from the variations in the levels of contamination, source of contamination, period of exposure, the characteristics of the environment and variations of metal or metalloid bioavailability (Aguilar et al., 2020). The cases of the strains belonging to the Actinobacteria phylum, R. gordoniae and M.hydrocarbonoxydans were slightly more efficient in the removal of $\mathrm{As}(\mathrm{III}), 81.6 \pm 1.1 \%$ and $79.98 \pm 2.2 \%$; while for $\mathrm{As}(\mathrm{V})$ they were $77.21 \pm 0.9 \%$ and $68.93 \pm 2.8 \%$, respectively, (Figure 6 (b, c)). For both genders, in comparison with previous work (A. Corsini et al., 2014; Pandey \& Bhatt, 2016b; Prasad et al., 2011), the results obtained were within the reported range of $48.43 \%$ to greater than $90 \%$, Table 5. The possible explanation between the removal capacity of $\mathrm{As}(\mathrm{III})$ and $\mathrm{As}(\mathrm{V})$ by $R$. gordionae and $M$. hydrocarbonoxydans, observed in this study, is that they can present systems capable of both reducing and oxidizing As. The transformation reactions are not only affected by the bacterial functional enzymes, but also the reduction/ oxidation potential in the environment, which is greatly influenced by the presence of microbial communities. There is information on As redox cycling by microorganisms which play a significant role in controlling As speciation and mobility in high As environments. In this study, it was observed that P. kribbensis was able to remove up to $80.23 \pm 0.3 \%$ of $\mathrm{As}(\mathrm{V})$, Figure $6(\mathrm{~d})$. However, it presented limitations to removing As(III) (section 3.3). It is well documented that As toxicity depends on its chemical form, with inorganic forms being the most toxic. In most of the reported cases, the percentage of As taken up by bacteria is higher with As $(\mathrm{V})$ due to it having lower toxicity than As(III) (Aguilar et al., 2020). Arsenate is taken up into the cell membrane by phosphate transporters, once $\mathrm{As}(\mathrm{V})$ binds to phosphate, the cell cannot detect its presence, it being highly accumulated in the cell. Moreover, this behavior is related to the fact that the bacteria can use the energy generated by As(V) reduction. It is worth mentioning that, this bacterium has been little studied, since it was recently discovered (D. H. Chang et al., 2016). Therefore, this is the first time that As removal studies by $P$. kribbensis have been presented.

\subsection{Possible mechanisms that play a role in removal of As in isolated strain. By means of a bioinformatic} analysis that was carried out on the bacteria identified in this work, it is considered that the detoxification of arsenic, $R$. gordoniae possibly uses the system operon ars, which transports arsenite out of the cell (A. Corsini et al., 2014). This operon includes a cytoplasmic arsenate reductase (arsC) that uses reduced glutathione (GSH) to convert arsenate to arsenite. ArsC forms an active complex with GSH, arsenate, and glutaredoxin (GRX). The final product, arsenite, is the substrate of the ArsA-ArsB efflux pump that renders the cells resistant to Asals. The 5gene operon, arsRDABC, where appear the Ars A (ATPase) and Ars D (Chaperone), conferring resistance to higher As levels and exerting a tighter regulation (Cavalca et al., 2013; Saiki, 1990), both being in different replicons, chromosomal type. It should be noted that R.gordoniae does not have one ars operon, but 2 ars operons on its chromosome (RBC and RADBC), which is the reason this bacterium has a very high resistance to As. For $E$. indicum HHS 31 and P. kribbensis CHA-19, Pseudomonas generally have at least one arsRBC operon that contains the enzyme arsenate reductase referenced as ArsC that is part of a system for detoxifying arsenate. The substrate binds to a catalytic cysteine residue, forming a covalent thiolate-As(V) intermediate. A tertiary intermediate is then formed between the As, the enzyme's cysteine, and a glutathione cysteine. This intermediate is reduced by glutaredoxin, which forms a dithiol with the glutathione, leading to the dissociation of arsenite which can be extruded from some bacteria by arsenite-transporting ATPase. This System also contains Spx, a general regulator that exerts negative and positive control over transcription initiation by binding to the $\mathrm{C}$-terminal domain of the alpha subunit of RNA polymerase (Cavalca et al., 2013). For the case of the detoxification mechanism detected in M. hydrocarbonoxydans SA35, Macur, et al (Macur et al., 2004) have reported that the mechanism of As(III) oxidation by Microbacterium is related to As detoxification rather than energy generation. 
Arsenate is acquired by an organism through endogenous Pi (inorganic phosphate) transport systems. Inside the cell, arsenate is reduced to the thiol-reactive form arsenite. Glutathione (GSH)-conjugates of arsenite may be extruded from the cell or sequestered in vacuoles by members of the ATP-binding cassette (ABC) family of transporters, (LeBlanc et al., 2013). The isolation of both oxidizing and reducing strains from same species, shows that the ability to either oxidize As(III) or reduce As(V) is variable even among strains that proliferate under the same environmental conditions. Figure 7 shows the likely mechanism of microbial transformations of arsenic: a) In detoxification and energy generation, arsenite oxidase (Aio) is responsible for the oxidation of $\mathrm{As}(\mathrm{III})$, arsenite functions as an electron donor in the initiation of a membrane respiratory chain, b) In arsenate reduction, energy generation, arsenate reductase (Arr) participates in the reduction of $A s(V)$, arsenate functions as a terminal electron acceptor for an anaerobic respiratory chain, $\mathrm{c}) \mathrm{As}(\mathrm{V})$ is taken up by organisms through phosphate transporters and As(III), being in an uncharged form, enters the cell through the aquaglyceroporin (GIpF) transporter. As(V) is then reduced to As(III) by bacterial ArsC. Glutathione and glutaredoxin serve as a source of reducing potential. Possibly, arsenite is extruded from cells only by ArsB, where energy is supplied by the cell membrane potential or by an arsenite translocating ATPase (ArsAB ATPase). The ArsA protein is an ATPase that interacts with ArsB to form the arsenite expulsion pump energized by ATP hydrolysis. The main function of Ars $D$ is related to its ability to bind arsenite and transfer it to the ArsA ATPase, prior to oxyanion expulsion by the ArsB pump. In general terms, it is worth mentioning that in the analysis of arsenic removal by microorganisms, the stress mechanisms employed by the microorganisms for their survival and acclimatization in arsenic-rich environments must also be considered. In the present study, R. gordoniae, M. hydrocarbonoxydans, E. indicum and P. kribbensis were found to be able to tolerate arsenic, as well as remove arsenite and arsenate. The results of the present study indicate that native microorganisms could be good candidates for the field of in situ bioremediation. Future prospects for research in this field could include the sustainable application of molecular tools and technologies. Recent advances in genetic engineering, including techniques such as gene editing, systems biology and metabolic engineering and nanozyme based bioremediation provide further insight into microbial metabolism and could be employed to improve bioremediation capabilities.

\section{Conclusions}

The application of microorganisms in the field of treatment of water contaminated by metalloids or metals is immense as remediation using microbial ecological methods is emerging as a promising technology. The search for sustainable biological techniques has been gaining momentum in recent times, and it is necessary to carry out more research oriented in the search, application and treatment of contaminated water or contaminated sites by microbial application. Bacteria from As contaminated sites are able to tolerate high levels of this metalloid and are capable of removing it. The results of the present study indicate that native microorganisms could be good candidates for bioremediation. Of the four bacterial species investigated, $R$. gordoniae and $M$.

hydrocarbonoxydans were adapted to a wider $\mathrm{pH}$ range and were able to tolerate higher $\mathrm{As}(\mathrm{III})$ and $\mathrm{As}(\mathrm{V})$ stress and could be chosen as potential candidates in bioremediation. However, the study of E. indicum and $P$. kribbensis also offers a potential field of research for As removal under optimal conditions.

\section{Declarations}

\section{Compliance with ethical standards}

Conflict of interest. The authors declare that they have no conflict of interest. 
Ethical approval. This article does not contain any studies with humans or animals performed by any of the authors.

\section{Acknowledgements}

The authors would like to acknowledge the Consejo Nacional de Ciencia y Tecnología (CONACYT) and the University of Guanajuato (Engineering Division and Directorate for Research and Postgraduate Support).

\section{References}

Aguilar, N. C., Faria, M. C. S., Pedron, T., Batista, B. L., Mesquita, J. P., Bomfeti, C. A., \& Rodrigues, J. L. (2020). Isolation and characterization of bacteria from a brazilian gold mining area with a capacity of arsenic bioaccumulation. Chemosphere, 240, 124871.

Andreasen, R., Li, Y., Rehman, Y., Ahmed, M., Meyer, R. L., \& Sabri, A. N. (2018). Prospective role of indigenous Exiguobacterium profundum PT 2 in arsenic biotransformation and biosorption by planktonic cultures and biofilms. Journal of applied microbiology, 124(2), 431-443.

Arroyo, Y. R., Muñoz, A. H., Barrientos, E. Y., Huerta, I. R., \& Wrobel, K. (2013). Natural decrease of dissolved arsenic in a small stream receiving drainages of abandoned silver mines in Guanajuato, Mexico. Bull Environ Contam Toxicol, 91(5), 539-544. https://doi.org/10.1007/s00128-013-1091-7

Arroyo-Herrera, I., Román-Ponce, B., Reséndiz-Martínez, A. L., Estrada-de Los Santos, P., Wang, E. T., \& VásquezMurrieta, M. S. (2021). Heavy-metal resistance mechanisms developed by bacteria from Lerma-Chapala basin. Arch Microbiol. https://doi.org/10.1007/s00203-020-02140-2

Castrejón, U. E. R., Muñoz, A. H. S., Jimenez, G. C., Canchoa, C. C., Vargas, A. Á., Ortega, N. G., Cadena, L. E. S., \& Puga, L. E. M. (2020). Characterization of arsenite oxidizing bacteria for wastewater treatment. JÓVENES EN LA CIENCIA, 8, 1-4.

Cavalca, L., Corsini, A., Zaccheo, P., Andreoni, V., \& Muyzer, G. (2013). Microbial transformations of arsenic: perspectives for biological removal of arsenic from water. Future Microbiol, 8(6), 753-

768. https://doi.org/10.2217/fmb.13.38

Chang, D.-H., Rhee, M.-S., Kim, J.-S., Lee, Y., Park, M. Y., Kim, H., Lee, S.-G., \& Kim, B.-C. (2016). Pseudomonas kribbensis sp. nov., isolated from garden soils in Daejeon, Korea. Antonie Van Leeuwenhoek, 109(11), $1433-1446$.

Chang, D. H., Rhee, M. S., Kim, J. S., Lee, Y., Park, M., Kim, H., Lee, S. G., \& Kim, B. C. (2016). Pseudomonas kribbensis sp nov., isolated from garden soils in Daejeon, Korea. Antonie Van Leeuwenhoek International Journal of General and Molecular Microbiology, 109(11), 1433-1446. https://doi.org/10.1007/s10482-016-0743-0

Chang, J.-S., Yoon, I.-H., Lee, J.-H., Kim, K.-R., An, J., \& Kim, K.-W. (2010). Arsenic detoxification potential of aox genes in arsenite-oxidizing bacteria isolated from natural and constructed wetlands in the Republic of Korea. Environmental geochemistry and health, 32(2), 95-105. 
Chaturvedi, P., \& Shivaji, S. (2006). Exiguobacterium indicum sp. nov., a psychrophilic bacterium from the Hamta glacier of the Himalayan mountain ranges of India. Int J Syst Evol Microbiol, 56(Pt 12), 2765-

2770. https://doi.org/10.1099/ijs.0.64508-0

Corsini, A., Zaccheo, P., Muyzer, G., Andreoni, V., \& Cavalca, L. (2014). Arsenic transforming abilities of groundwater bacteria and the combined use of Aliihoeflea sp. strain $2 W W$ and goethite in metalloid removal. $J$ Hazard Mater, 269, 89-97. https://doi.org/10.1016/j.jhazmat.2013.12.037

Corsini, A., Zaccheo, P., Muyzer, G., Andreoni, V., \& Cavalca, L. (2014). Arsenic transforming abilities of groundwater bacteria and the combined use of Aliihoeflea sp. strain 2WW and goethite in metalloid removal. Journal of Hazardous Materials, 269, 89-97. https://doi.org/https://doi.org/10.1016/j.jhazmat.2013.12.037

Element, C. A. S. (2007). Method 3015A Microwave assisted acid digestion of aqueous samples and extracts. Washington, DC: Environmental Protection Agency.

Gerhardt, P., Murray, R. G. E., Wood, W. A., \& Krieg, N. R. (1994). Methods for general and molecular bacteriology. American Society for Microbiology, Washington, DC. Stackebrandt E, Goebel BM, 607654.

Hamood Altowayti, W. A., Almoalemi, H., Shahir, S., \& Othman, N. (2020). Comparison of culture-independent and dependent approaches for identification of native arsenic-resistant bacteria and their potential use for arsenic bioremediation. Ecotoxicol Environ Saf, 205, 111267. https://doi.org/10.1016/j.ecoenv.2020.111267

Jones, A. L., Brown, J. M., Mishra, V., Perry, J. D., Steigerwalt, A. G., \& Goodfellow, M. (2004). Rhodococcus gordoniae sp. nov., an actinomycete isolated from clinical material and phenol-contaminated soil. International journal of systematic and evolutionary microbiology, 54(2), 407-411.

Kao, A.-C., Chu, Y.-J., Hsu, F.-L., \& Liao, V. H.-C. (2013). Removal of arsenic from groundwater by using a native isolated arsenite-oxidizing bacterium. Journal of contaminant hydrology, 155, 1-8.

Kirchman, D., Sigda, J., Kapuscinski, R., \& Mitchell, R. (1982). Statistical analysis of the direct count method for enumerating bacteria. Applied and Environmental Microbiology, 44(2), 376-382.

Kruger, M. C., Bertin, P. N., Heipieper, H. J., \& Arsène-Ploetze, F. (2013). Bacterial metabolism of environmental arsenic--mechanisms and biotechnological applications. App/ Microbiol Biotechnol, 97(9), 3827-

3841. https://doi.org/10.1007/s00253-013-4838-5

Kumari, N., Rana, A., \& Jagadevan, S. (2019). Arsenite biotransformation by Rhodococcus sp.: Characterization, optimization using response surface methodology and mechanistic studies. Sci Total Environ, 687, 577589. https://doi.org/10.1016/j.scitotenv.2019.06.077

Larkin, M. A., Blackshields, G., Brown, N. P., Chenna, R., McGettigan, P. A., McWilliam, H., Valentin, F., Wallace, I. M., Wilm, A., \& Lopez, R. (2007). Clustal W and Clustal X version 2.0. bioinformatics, 23(21), 2947-2948.

LeBlanc, M. S., McKinney, E. C., Meagher, R. B., \& Smith, A. P. (2013). Hijacking membrane transporters for arsenic phytoextraction. Journal of biotechnology, 163(1), 1-9. 
Loredo-Portales, R., Castillo-Michel, H., Aquilanti, G., De La Rosa-Álvarez, M. G., Rocha-Amador, D. O., Vogel-Mikus, K., Kump, P., \& Cruz-Jiménez, G. (2017). Synchrotron based study of As mobility and speciation in tailings from a mining site in Mexico. Journal of environmental chemical engineering, 5(1), 1140-1149.

Macur, R. E., Jackson, C. R., Botero, L. M., McDermott, T. R., \& Inskeep, W. P. (2004). Bacterial populations associated with the oxidation and reduction of arsenic in an unsaturated soil. Environmental science \& technology, 38(1), 104-111.

Mirza, B. S., Sorensen, D. L., Dupont, R. R., \& McLean, J. E. (2017). New arsenate reductase gene (arrA) PCR primers for diversity assessment and quantification in environmental samples. Applied and environmental microbiology, 83(4).

Monterrey, I. P. D. PROYECTO DE NORMA OFICIAL MEXICANA PROY-NOM-127-SSA1-2017, AGUA PARA USO Y CONSUMO HUMANO. LÍMITES PERMISIBLES DE LA CALIDAD DEL AGUA.

Mudzielwana, R., Gitari, M. W., Akinyemi, S. A., Talabi, A. O., \& Ndungu, P. (2020). Hydrogeochemical characteristics of arsenic rich groundwater in Greater Giyani Municipality, Limpopo Province, South Africa. Groundwater for Sustainable Development, 10, 100336.

Murray, M. G., \& Thompson, W. F. (1980). Rapid isolation of high molecular weight plant DNA. Nucleic acids research, 8(19), 4321-4326.

Muñoz, A. H. S., García, M. G. M., García, F. A. V., Luna, B. N., Molina, A. Z., Li, Y., \& Castrejón, U. E. R. (2016). Uso potencial de pellets para el tratamiento de aguas contaminadas con arsénico en comunidades de Xichú, Gto., México. Acta Universitaria, 26(2), 22-32. https://doi.org/10.15174/au.2016.1502

Nordstrom, D. K. (2002). Public health. Worldwide occurrences of arsenic in ground water. Science, 296(5576), 2143-2145. https://doi.org/10.1126/science.1072375

Ono, F. B., Tappero, R., Sparks, D., \& Guilherme, L. R. G. (2016). Investigation of arsenic species in tailings and windblown dust from a gold mining area. Environmental Science and Pollution Research, 23(1), 638-647.

Osuna-Martínez, C. C., Armienta, M. A., Bergés-Tiznado, M. E., \& Páez-Osuna, F. (2020). Arsenic in waters, soils, sediments, and biota from Mexico: An environmental review. Science of The Total Environment, 142062.

Pandey, N., \& Bhatt, R. (2015). Exiguobacterium mediated arsenic removal and its protective effect against arsenic induced toxicity and oxidative damage in freshwater fish, Channa striata. Toxicology Reports, 2, 13671375. https://doi.org/https://doi.org/10.1016/j.toxrep.2015.10.002

Pandey, N., \& Bhatt, R. (2016a). Arsenic Removal and Biotransformation Potential of Exiguobacterium Isolated From an Arsenic-Rich Soil of Chhattisgarh, India [https://doi.org/10.1002/clen.201500095]. CLEAN - Soil, Air, Water, 44(2), 211-218. https://doi.org/https://doi.org/10.1002/clen.201500095

Pandey, N., \& Bhatt, R. (2016b). Role of soil associated Exiguobacterium in reducing arsenic toxicity and promoting plant growth in Vigna radiata. European Journal of Soil Biology, 75, 142-150. 
Prasad, K. S., Srivastava, P., Subramanian, V., \& Paul, J. (2011). Biosorption of As(III) lon on Rhodococcus sp. WB12: Biomass Characterization and Kinetic Studies. Separation Science and Technology, 46(16), 25172525. https://doi.org/10.1080/01496395.2011.597040

Rodríguez, U. E., Serafínb, A. H., Canoc, M. C., Gutiérrezb, N. L., \& Álvarezc, A. (2019). Isolation and Molecular Identification of Arsenic Resistant Microorganisms Coming from Xichu River, Gto. Mexico. CHEMICAL ENGINEERING, 74.

Saiki, R. K. (1990). Amplification of genomic DNA. PCR protocols: A guide to methods and applications, 2, 13-20.

Saitou, N., \& Nei, M. (1987). The neighbor-joining method: a new method for reconstructing phylogenetic trees. Molecular biology and evolution, 4(4), 406-425.

Sayers, E. W., Beck, J., Bolton, E. E., Bourexis, D., Brister, J. R., Canese, K., Comeau, D. C., Funk, K., Kim, S., \& Klimke, W. (2021). Database resources of the national center for biotechnology information. Nucleic acids research, 49(D1), D10.

Sayers, E. W., Cavanaugh, M., Clark, K., Pruitt, K. D., Schoch, C. L., Sherry, S. T., \& Karsch-Mizrachi, I. (2021). GenBank. Nucleic acids research, 49(D1), D92-D96.

Schippers, A., Bosecker, K., Spröer, C., \& Schumann, P. (2005). Microbacterium oleivorans sp. nov. and Microbacterium hydrocarbonoxydans sp. nov., novel crude-oil-degrading Gram-positive bacteria. Int J Syst Evol Microbiol, 55(Pt 2), 655-660. https://doi.org/10.1099/ijs.0.63305-0

Schwartz, S., Zhang, Z., Frazer, K. A., Smit, A., Riemer, C., Bouck, J., Gibbs, R., Hardison, R., \& Miller, W. (2000). PipMaker-a web server for aligning two genomic DNA sequences. Genome research, 10(4), 577-586.

Tsuchiya, T., Ehara, A., Kasahara, Y., Hamamura, N., \& Amachi, S. (2019). Expression of genes and proteins involved in arsenic respiration and resistance in dissimilatory arsenate-reducing Geobacter sp. strain OR-1. Applied and environmental microbiology, 85(14).

Tuzen, M., Citak, D., Mendil, D., \& Soylak, M. (2009). Arsenic speciation in natural water samples by coprecipitation-hydride generation atomic absorption spectrometry combination. Talanta, 78(1), 5256. https://doi.org/10.1016/j.talanta.2008.10.035

Wang, L., Yin, Z., \& Jing, C. (2020). Metagenomic insights into microbial arsenic metabolism in shallow groundwater of Datong basin, China. Chemosphere, 245,

125603. https://doi.org/10.1016/j.chemosphere.2019.125603

World Health, O. (2018). A global overview of national regulations and standards for drinking-water quality.

\section{Tables}

Table 1. In-situ physico-chemical characterization of water samples in dry season. Level and Standard Deviation $(\mathrm{SD}), \mathrm{n}=3$. 


\begin{tabular}{|c|c|c|c|c|}
\hline \multirow[t]{2}{*}{ Parameters } & \multicolumn{4}{|c|}{ Sampling points } \\
\hline & AJ & $J$ & EJ & DJ \\
\hline $\mathrm{SO}_{4}{ }^{2-}\left(\mathrm{mg} \mathrm{L}^{-1}\right)$ & $110 \pm 1.1$ & $132.5 \pm 1.3$ & $145 \pm 2.1$ & $160 \pm 2.1$ \\
\hline $\mathrm{pH}$ & $8.1 \pm 0.1$ & $9.1 \pm 0.2$ & $8.5 \pm 0.9$ & $9.2 \pm 1.5$ \\
\hline $\mathrm{S}^{2-}\left(\mathrm{mg} \mathrm{L}^{-1}\right)$ & n.d. & n.d. & n.d. & n.d. \\
\hline C.E $\left(\mu \mathrm{Scm}^{-1}\right)$ & $630 \pm 1.5$ & $957 \pm 2.1$ & $653 \pm 3.2$ & $661 \pm 2.6$ \\
\hline O.D $\left(\mathrm{mg} \mathrm{L}^{-1}\right)$ & $5.7 \pm 0.9$ & $4.68 \pm 0.1$ & $4.18 \pm 0.6$ & $4.45 \pm 0.1$ \\
\hline $\mathrm{T}\left({ }^{\circ} \mathrm{C}\right)$ & $28.0 \pm 1.8$ & $29.5 \pm 0.4$ & $29.6 \pm 1.6$ & $27.8 \pm 1.2$ \\
\hline $\mathrm{Fe}^{2+}\left(\mathrm{mg} \mathrm{L}^{-1}\right)$ & $0.04 \pm 0.01$ & $0.036 \pm 0.01$ & $0.042 \pm 1.6$ & $0.08 \pm 0.01$ \\
\hline $\mathrm{NO}_{3}^{-}\left(\mathrm{mg} \mathrm{L}^{-1}\right)$ & $9.6 \pm 1.8$ & $1.25 \pm 1.02$ & $6.8 \pm 2.1$ & $0.9 \pm 0.01$ \\
\hline $\mathrm{K}^{+}\left(\mathrm{mg} \mathrm{L}^{-1}\right)$ & $1.8 \pm 0.1$ & $1.9 \pm 0.22$ & $1.29 \pm 0.14$ & $2.9 \pm 0.33$ \\
\hline $\mathrm{Mg}^{2+}\left(\mathrm{mg} \mathrm{L}^{-1}\right)$ & $33.2 \pm 1.88$ & $38.1 \pm 1.92$ & $30.9 \pm 1.01$ & $32.01 \pm 2.42$ \\
\hline $\mathrm{Mn}^{2+}\left(\mathrm{mg} \mathrm{L}^{-1}\right)$ & $0.27 \pm 0.03$ & $0.38 \pm 0.02$ & $0.01 \pm 0.01$ & $0.15 \pm 0.02$ \\
\hline $\mathrm{Zn}^{2+}\left(\mathrm{mg} \mathrm{L}^{-1}\right)$ & $0.012 \pm 0.01$ & $0.045 \pm 0.01$ & $0.035 \pm 0.001$ & $0.027 \pm 0.01$ \\
\hline
\end{tabular}

n.d.= not detected

Table 2. Determination of Arsenic concentration $\left(\mu \mathrm{g} \mathrm{L}^{-1}\right)$ in water samples by HG-AAS.

\begin{tabular}{|c|c|c|c|c|}
\hline \multirow[t]{3}{*}{ Water samples } & \multicolumn{4}{|c|}{ Sampling point } \\
\hline & AJ & $\mathrm{J}$ & EJ & DJ \\
\hline & $35.02 \pm 0.2$ & $40.5 \pm 1.1$ & $50.3 \pm 2.9$ & $108.1 \pm 2.1$ \\
\hline
\end{tabular}

**Genes identified in this work

n.d: not detected

Table 3. Summary of the Molecular Identification. 


\begin{tabular}{|lll|}
\hline Isolated strains & Closely related species & Acces numbers GenBank \\
\hline 1DA & Rhodococcus gordoniae & NR_025730.1 \\
\hline 3DS & Pseudomonas kribbensis & KT321658.1 \\
4DA & Exiguobacterium indicum & MT256271.1 \\
\hline 13DB & Microbacterium hydrocarbonoxydans & MK424292.1 \\
\hline
\end{tabular}

Table 4. Results of molecular identification.

\begin{tabular}{|lllll|}
\hline Key & Genus & Phylum & Tinción Gram & Genotype* \\
\hline 1DA & Rhodococcus & Actinobacteria & positive & n.d \\
\hline 3DS & Pseudomonas & Proteobacteria & negative & ars C, aioA** \\
\hline 4DA & Exiguobacterium & Firmicutes & Positive & ars C, aioA** \\
\hline 13DB & Microbacterium & Actinobacteria & Positive & ars C, aioA ${ }^{\star \star}$ \\
\hline
\end{tabular}

**Genes identified in this work

n.d: not detected

Table 5. Summary of bioremediation efficiency of various bacterial species. 


\begin{tabular}{|c|c|c|c|c|c|}
\hline Bacteria & $\begin{array}{l}\text { Source of } \\
\text { isolation }\end{array}$ & $\begin{array}{l}\text { Media used } \\
\text { for As } \\
\text { remediation }\end{array}$ & $\begin{array}{l}\text { Method of } \\
\text { remediation } \\
\text { employed by } \\
\text { bacteria }\end{array}$ & $\begin{array}{l}\text { Remediation } \\
\text { efficiency }\end{array}$ & Reference \\
\hline Exiguobacterium sp. & $\begin{array}{l}\text { Soil from } \\
\text { Rajnandgaon, } \\
\text { Chhattisgarh, } \\
\text { India }\end{array}$ & $\begin{array}{l}\text { Basal Salt } \\
\text { Medium } \\
\text { (BSM) }\end{array}$ & Biosorption & $\begin{array}{l}99 \% \text { of As } \\
(\mathrm{V}), \\
90 \% \text { of As } \\
(\mathrm{III})\end{array}$ & $\begin{array}{l}\text { (Pandey \& } \\
\text { Bhatt, } \\
\text { 2016b) }\end{array}$ \\
\hline Exiguobacterium sp. & $\begin{array}{l}\text { Soil from } \\
\text { Chhattisgarh, } \\
\text { India }\end{array}$ & $\begin{array}{l}\text { Water } \\
\text { samples }\end{array}$ & $\begin{array}{l}\text { Immobilized in } \\
\text { calcium alginate }\end{array}$ & $\begin{array}{l}99 \% \text { of As } \\
\text { (III) }\end{array}$ & $\begin{array}{l}\text { (Pandey \& } \\
\text { Bhatt, } \\
\text { 2015) }\end{array}$ \\
\hline Exiguobacterium sp. & $\begin{array}{l}\text { Subsurface } \\
\text { soil from } \\
\text { Chhattisgarh, } \\
\text { India }\end{array}$ & $\begin{array}{l}\text { Basal salt } \\
\text { medium(BSM) }\end{array}$ & $\begin{array}{l}\text { Biosorption, } \\
\text { bio-oxidation }\end{array}$ & $\begin{array}{l}99 \% \text { arsenic } \\
\text { under } \\
\text { aerobic } \\
\text { conditions }\end{array}$ & $\begin{array}{l}\text { (Pandey \& } \\
\text { Bhatt, } \\
\text { 2016a) }\end{array}$ \\
\hline $\begin{array}{l}\text { Exiguobacterium } \\
\text { profundum } \\
\text { PT2 }\end{array}$ & $\begin{array}{l}\text { Wastewater } \\
\text { samples were } \\
\text { collected } \\
\text { from } \\
\text { the outer } \\
\text { drain of an } \\
\text { industrial } \\
\text { paint plant, } \\
\text { Kasur, } \\
\text { Pakistan }\end{array}$ & $\begin{array}{l}\text { Planktonic } \\
\text { cultures and } \\
\text { biofilms }\end{array}$ & $\begin{array}{l}\text { Biosorption } \\
\text { and } \\
\text { biotransformation }\end{array}$ & $\begin{array}{l}25.2 \text { and } \\
29.4 \mathrm{mg} \mathrm{g}^{-1} \\
\text { biomass, } \\
\text { respectively }\end{array}$ & $\begin{array}{l}\text { (Andreasen } \\
\text { et al., 2018) }\end{array}$ \\
\hline $\begin{array}{l}\text { Microbacterium } \\
\text { paraoxydansis }\end{array}$ & $\begin{array}{l}\text { Soil samples } \\
\text { from } \\
\text { districts of } \\
\text { Chhattisgarh, } \\
\text { India. }\end{array}$ & $\begin{array}{l}\text { Basal salt } \\
\text { medium } \\
(\mathrm{BSM})\end{array}$ & Biosorption & $\begin{array}{l}87 \pm 0.9 \% \text { of } \\
\text { As (III) }\end{array}$ & $\begin{array}{l}\text { (Pandey \& } \\
\text { Keshavkant, } \\
\text { 2019) }\end{array}$ \\
\hline $\begin{array}{l}\text { Microbacterium sp. } \\
\text { CSA40 }\end{array}$ & $\begin{array}{l}\text { Generation of } \\
\text { biogenic } \\
\text { manganese } \\
\text { oxides } \\
\text { (BMnOx) }\end{array}$ & Groundwater & $\begin{array}{l}\text { Biosorption, } \\
\text { bio-oxidation }\end{array}$ & $\begin{array}{l}>90 \% \text { of } \\
\text { total As was } \\
\text { removed by } \\
0.5 \mathrm{~g} / \mathrm{L} \\
\text { BMnOx }\end{array}$ & $\begin{array}{l}\text { (Liang et al., } \\
2017 \text { ) }\end{array}$ \\
\hline $\begin{array}{l}\text { Pseudomonas } \\
\text { genus, } \\
\text { As7325 }\end{array}$ & $\begin{array}{l}\text { Sediment and } \\
\text { groundwater } \\
\text { from } \\
\text { Southern } \\
\text { Zhuoshui } \\
\text { River alluvial } \\
\text { fan of } \\
\text { Taiwan }\end{array}$ & $\begin{array}{l}\text { Artificial } \\
\text { groundwater }\end{array}$ & Bio-oxidation & $\begin{array}{l}\text { As7325 } \\
\text { oxidized } \\
15000 \mu \mathrm{I}^{-1} \\
\text { As(III) to } \\
\text { As(V) }\end{array}$ & $\begin{array}{l}\text { (Kao et al., } \\
2013)\end{array}$ \\
\hline $\begin{array}{l}\text { Pseudomonas } \\
\text { aeruginosa, } \\
\text { AT-01 }\end{array}$ & $\begin{array}{l}\text { Groundwater } \\
\text { from } \\
\text { Pakistan }\end{array}$ & $\begin{array}{l}\text { Luria Bertani } \\
\text { broth } \\
\text { supplemented }\end{array}$ & Biosorption & $\begin{array}{l}\text { Remove As } \\
\text { with } 98 \% \\
\text { efficiency }\end{array}$ & $\begin{array}{l}\text { (Tariq et al., } \\
\text { 2019) }\end{array}$ \\
\hline $\begin{array}{l}\text { Rhodococcus sp. } \\
\text { MTCC } 4400\end{array}$ & $\begin{array}{l}\text { MTCC } \\
\text { Chandigarh }\end{array}$ & $\begin{array}{l}\text { Minimal } \\
\text { media (with } \\
\text { yeast }\end{array}$ & $\begin{array}{l}\text { Biosorption, } \\
\text { bioaccumulation } \\
\text { accompanied }\end{array}$ & $\begin{array}{l}80.2 \% \text { total } \\
\mathrm{As}(\mathrm{III})\end{array}$ & $\begin{array}{l}\text { (Kumari et } \\
\text { al., 2019) }\end{array}$ \\
\hline
\end{tabular}




\begin{tabular}{|c|c|c|c|c|c|}
\hline & (India) & Extract) & $\begin{array}{l}\text { with bio- } \\
\text { oxidation }\end{array}$ & $\begin{array}{l}\text { removed in } \\
12 \mathrm{~h} \text { for } \\
500 \mu \mathrm{M}\end{array}$ & \\
\hline & & $\begin{array}{l}\text { Artificial } \\
\text { groundwater }\end{array}$ & & $\begin{array}{l}48.43 \% \text { total } \\
\text { As(III) } \\
\text { removed in } \\
6 \mathrm{~h} \text { for } 500 \\
\mathrm{ppb}\end{array}$ & \\
\hline Rhodococcus sp. & $\begin{array}{l}\text { Subsurface } \\
\text { water sample } \\
\text { from } \\
\text { contaminated } \\
\text { site of West } \\
\text { Bengal, India }\end{array}$ & $\begin{array}{l}\text { Batch scale by } \\
\text { adding a } \\
\text { different } \\
\text { amount of } \\
\text { sorbent } \\
\text { (Biomass) }\end{array}$ & Biosorption & $\begin{array}{l}77.3 \mathrm{mg} / \mathrm{g} \\
\text { of } \mathrm{As}(\mathrm{III})\end{array}$ & $\begin{array}{l}\text { (Prasad et } \\
\text { al., 2011) }\end{array}$ \\
\hline $\begin{array}{l}\text { Rhodococcus sp. } \\
\text { strain } 6 \mathrm{G}\end{array}$ & $\begin{array}{l}\text { Water } \\
\text { samples from } \\
\text { the Province } \\
\text { of Cremona, } \\
\text { Lombardia, } \\
\text { Italy }\end{array}$ & $\begin{array}{l}\text { BBWM culture } \\
\text { medium }\end{array}$ & Bio-oxidation & $\begin{array}{l}75 \mathrm{mgL}^{-1} \\
\text { As(III) in } 48 \\
\mathrm{~h} \text {, }\end{array}$ & $\begin{array}{l}\text { (Anna } \\
\text { Corsini et } \\
\text { al., 2014) }\end{array}$ \\
\hline $\begin{array}{l}\text { Exiguobacterium } \\
\text { indicum }\end{array}$ & $\begin{array}{l}\text { Water } \\
\text { samples from } \\
\text { the Xichu } \\
\text { River (mining } \\
\text { area), }\end{array}$ & $\begin{array}{l}\text { Artificial water } \\
\text { (Based on the } \\
\text { analysis of }\end{array}$ & $\begin{array}{l}\text { Biosorption, } \\
\text { bioaccumulation }\end{array}$ & $\begin{array}{l}61.77 \% \text { of } \\
\text { As(III), } \\
74.83 \% \text { of } \\
\text { As(V) }\end{array}$ & This study \\
\hline $\begin{array}{l}\text { Microbacterium } \\
\text { hydrocarbonoxydans }\end{array}$ & Mexico & river) & & $\begin{array}{l}79.98 \% \text { of } \\
\text { As(III), } \\
68.93 \% \text { of } \\
\text { As(V) }\end{array}$ & This study \\
\hline $\begin{array}{l}\text { Rhodococcus } \\
\text { gordoniae }\end{array}$ & & & & $\begin{array}{l}81.6 \% \text { of } \\
\text { As(III), } \\
77.21 \% \text { of } \\
\text { As(V) }\end{array}$ & This study \\
\hline $\begin{array}{l}\text { Pseudomonas } \\
\text { kribbensis }\end{array}$ & & & & $\begin{array}{l}80.23 \% \text { of } \\
\mathrm{As}(\mathrm{V})\end{array}$ & This study \\
\hline
\end{tabular}

\section{Figures}




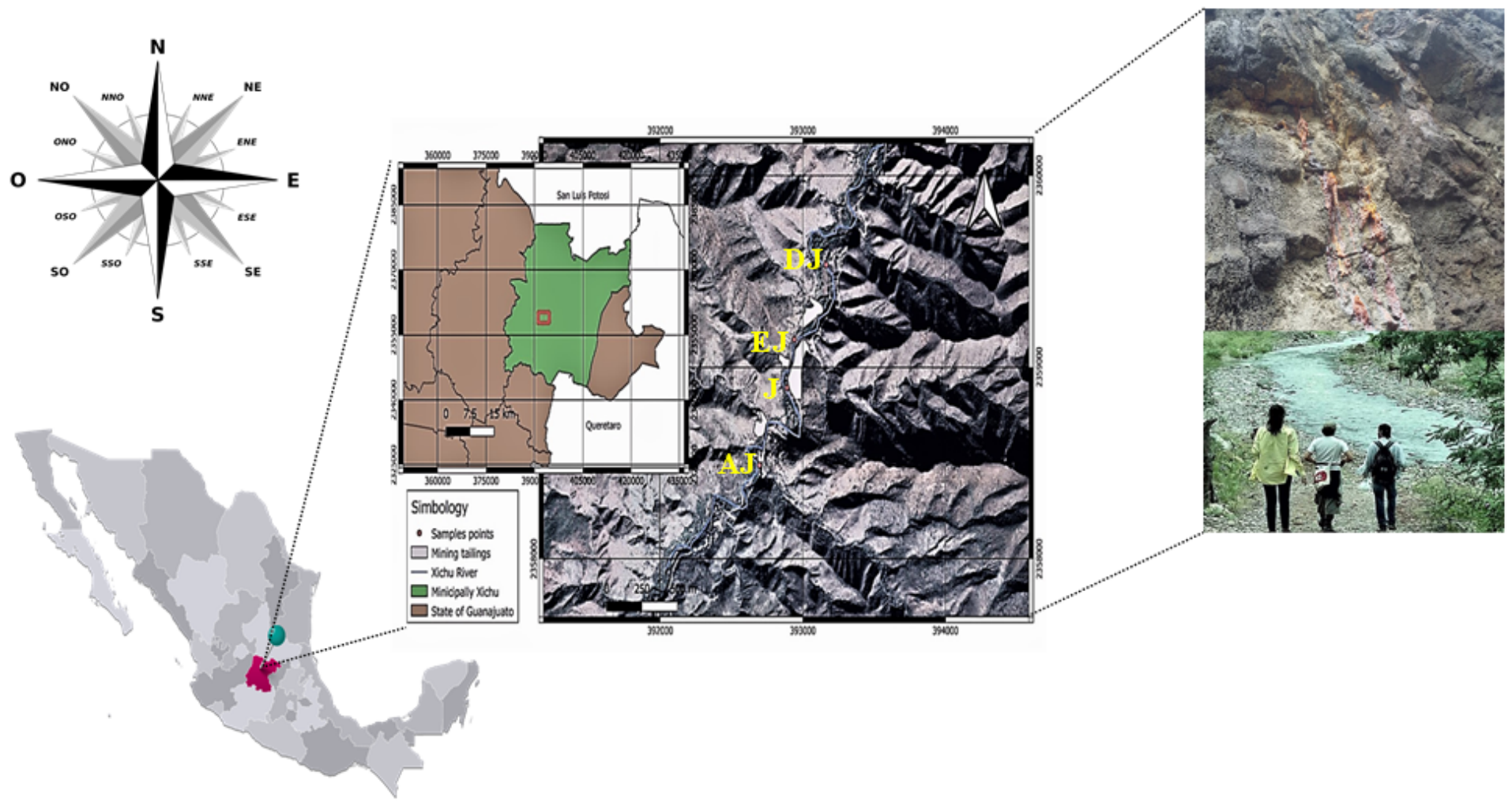

\section{Figure 1}

Sampling site, Xichu River, Guanajuato, Mexico. The location points were AJ (21 $\left.{ }^{\circ} 19^{\prime} 40.04^{\prime \prime} \mathrm{N}, 100^{\circ} 01^{\prime} 57.18^{\prime \prime} 0\right)$, EJ ( $\left.21^{\circ} 1952.88^{\prime \prime} \mathrm{N}, 100^{\circ} 01^{\prime} 54.09^{\prime \prime} \mathrm{O}\right), \mathrm{J}\left(21^{\circ} 19^{\prime} 48.13^{\prime \prime} \mathrm{N}, 100^{\circ} 01^{\prime} 57.89^{\prime \prime} \mathrm{O}\right)$ and DJ $\left(21^{\circ} 19^{\prime} 57.81^{\prime \prime} \mathrm{N}, 100^{\circ} 01\right.$ '48.87"0). The map was created by QGIS 3.14 software. Note: The designations employed and the presentation of the material on this map do not imply the expression of any opinion whatsoever on the part of Research Square concerning the legal status of any country, territory, city or area or of its authorities, or concerning the delimitation of its frontiers or boundaries. This map has been provided by the authors. 


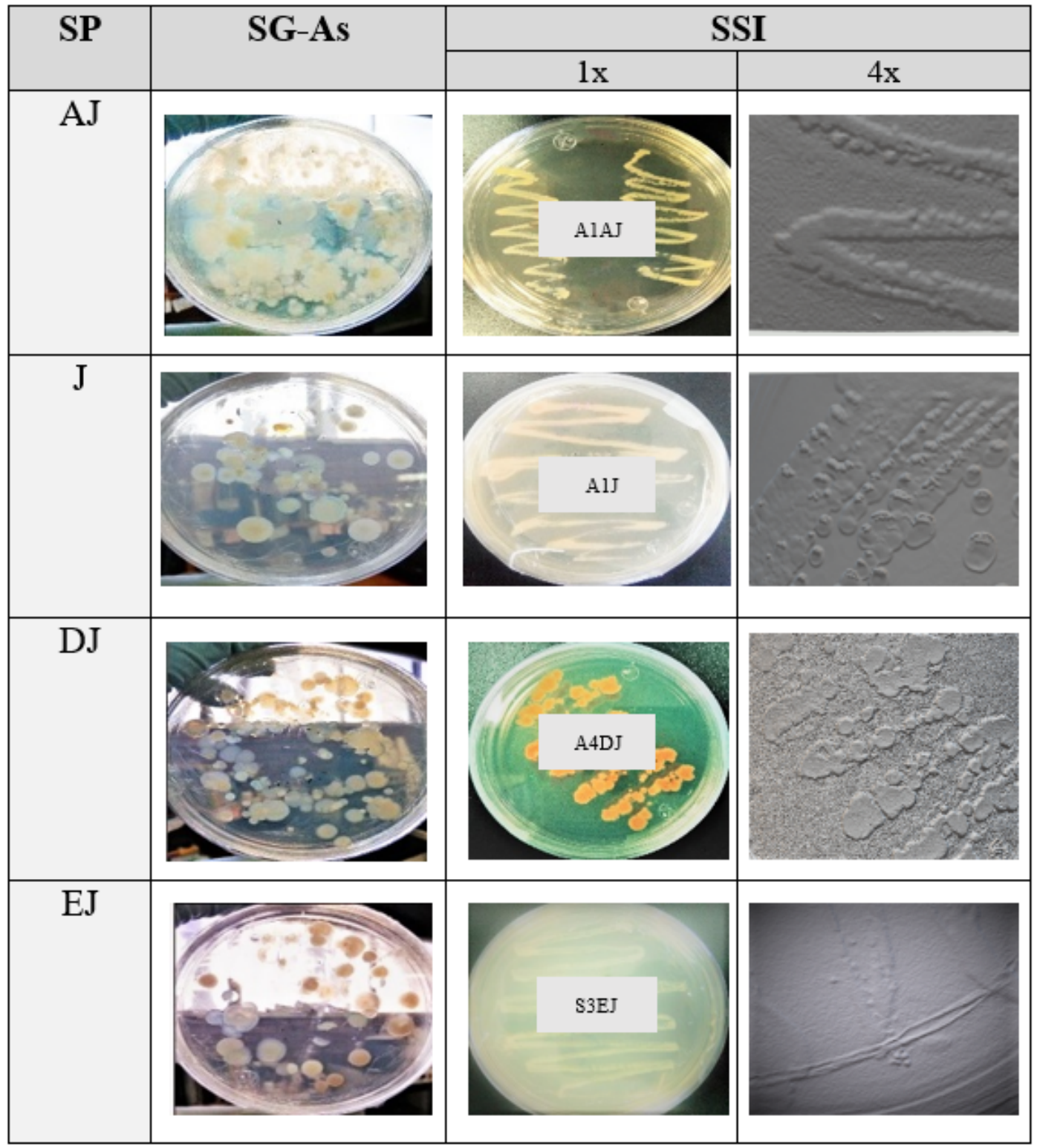

SP: Sampling point

SG-As: Strains grown on arsenic-containing media

SSI: Strain selected and isolated

\section{Figure 2}

Native strains obtained at the different sampling points. The second column shows the strains that grew in culture media with the presence of arsenic. The third and fourth columns show the growth of the isolated native strains, where the color of the strain ( $1 \mathrm{x}$, by optical microscopy) and the shape (4x, by $3 \mathrm{dp}$.rocks/lithophane software) can be appreciated. 


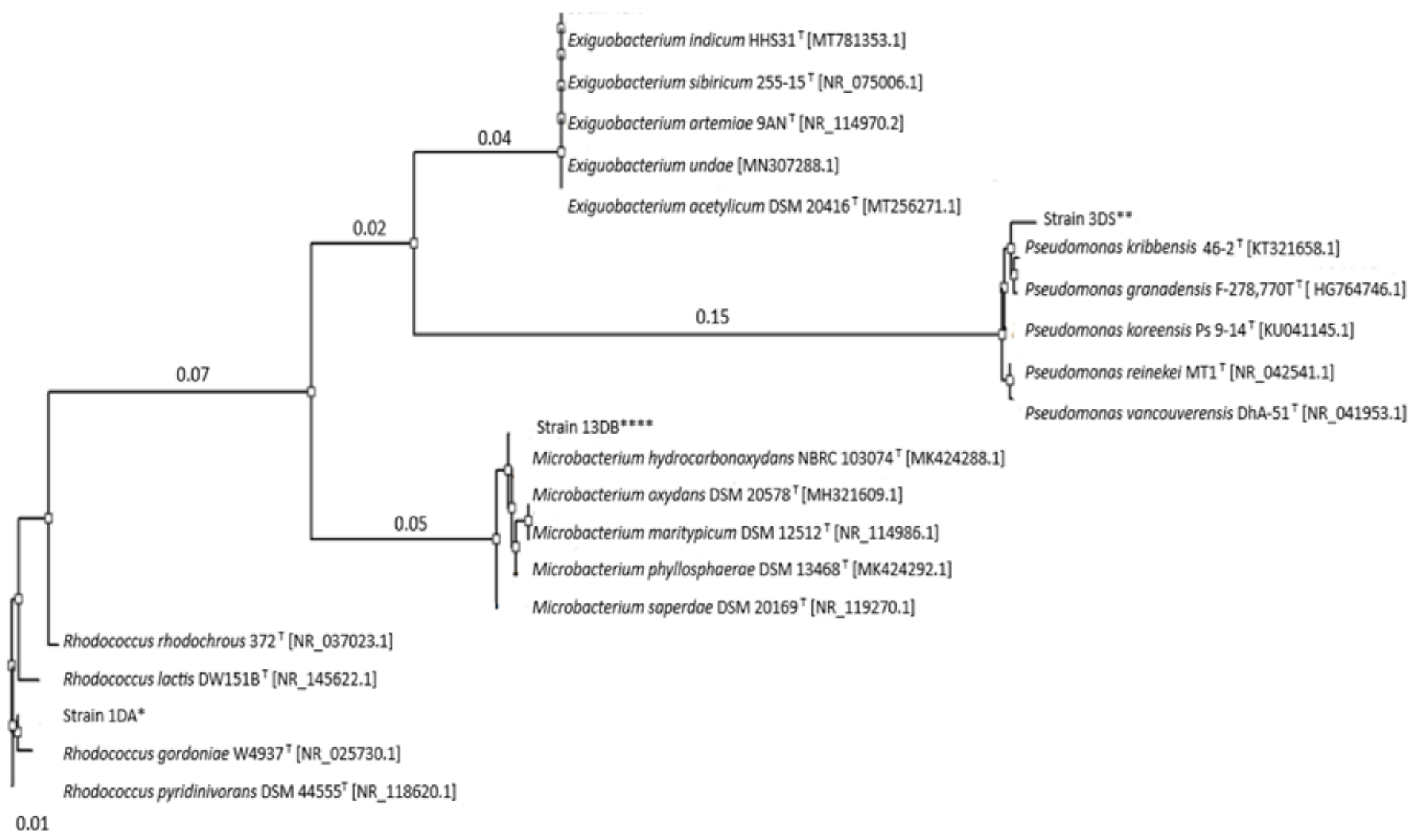

\section{Figure 3}

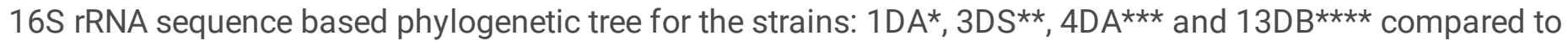
other bacteria in GenBank® by using the neighbor-joining method. Asterisks indicate our isolates. 


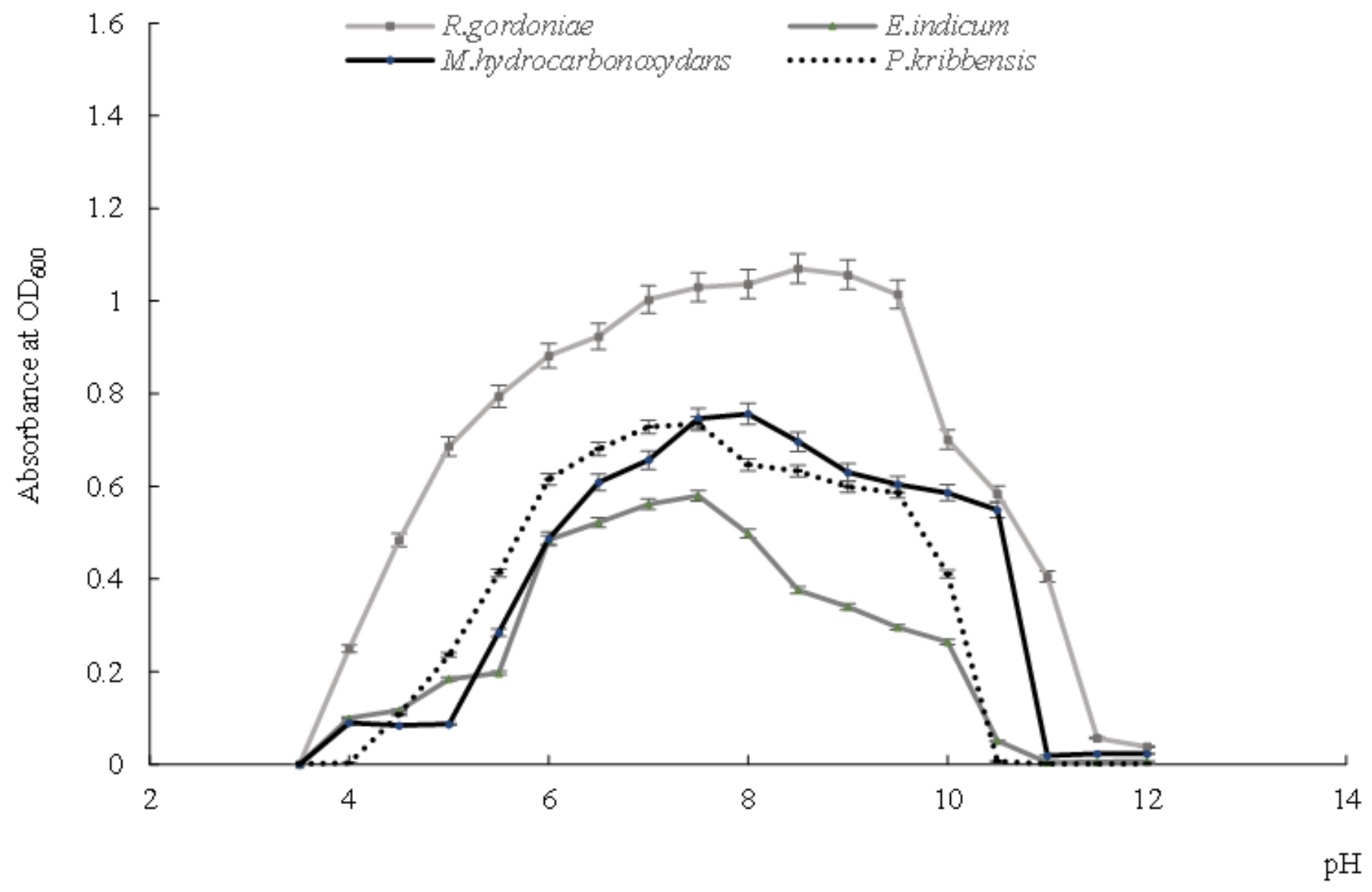

\section{Figure 4}

Growth of R.gordoniae, M.hydrocarbonoxydans, E.indicum and P.kribbensis under pH ranging from 3.5 to 12 . Change in OD600 of culture was measured over $24 \mathrm{~h}$ (error bars indicate the standard error of triplicate samples). 

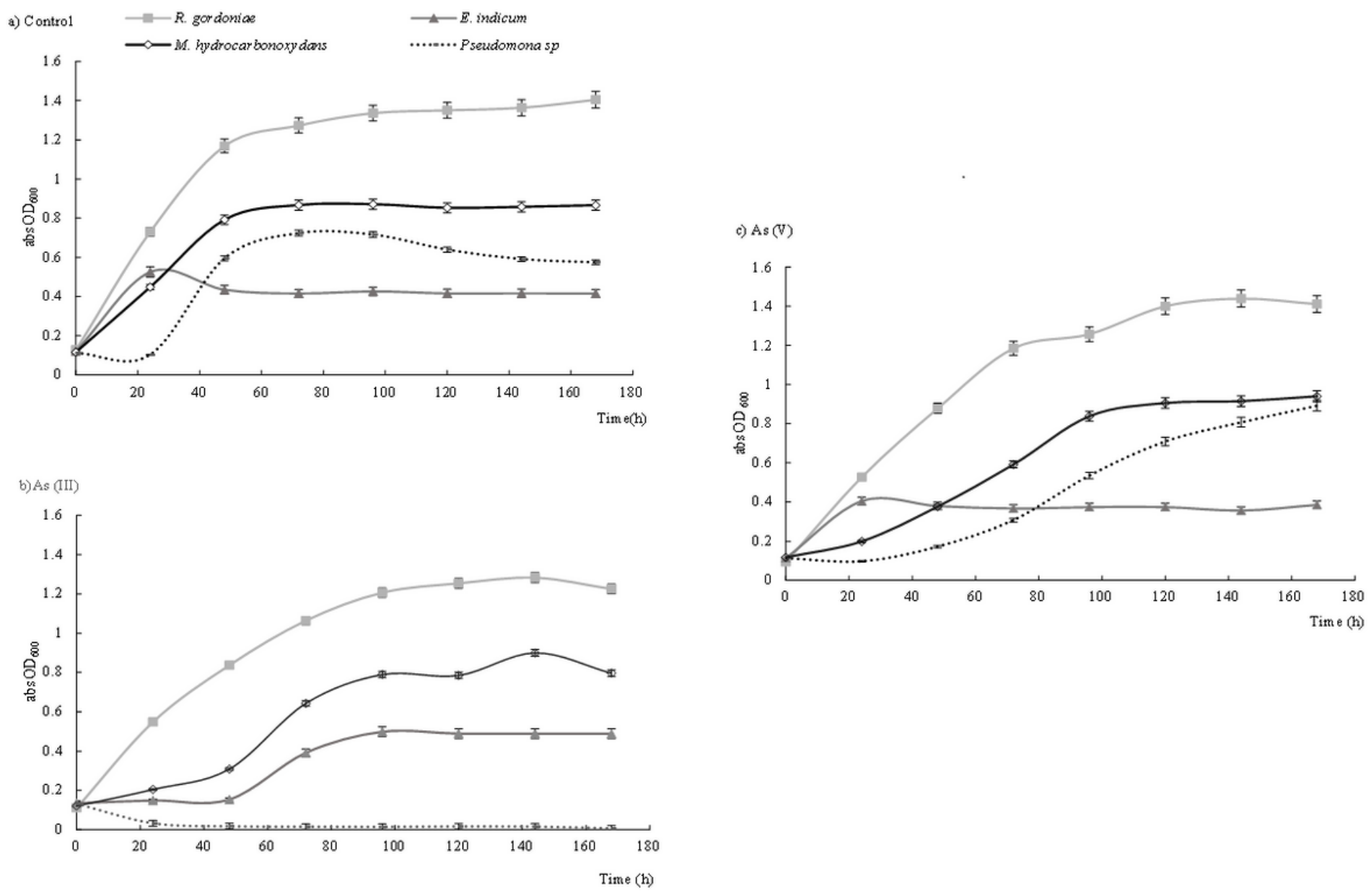

\section{Figure 5}

Growth of R.gordoniae, M. hydrocarbonoxydans, E.indicum and P. kribbensis, under concentration of inorganic arsenic species, $10 \mathrm{mM}$. a) Control, b) As(III) and c) As (V). Error bars indicate the standard error of the mean of three experiments. 

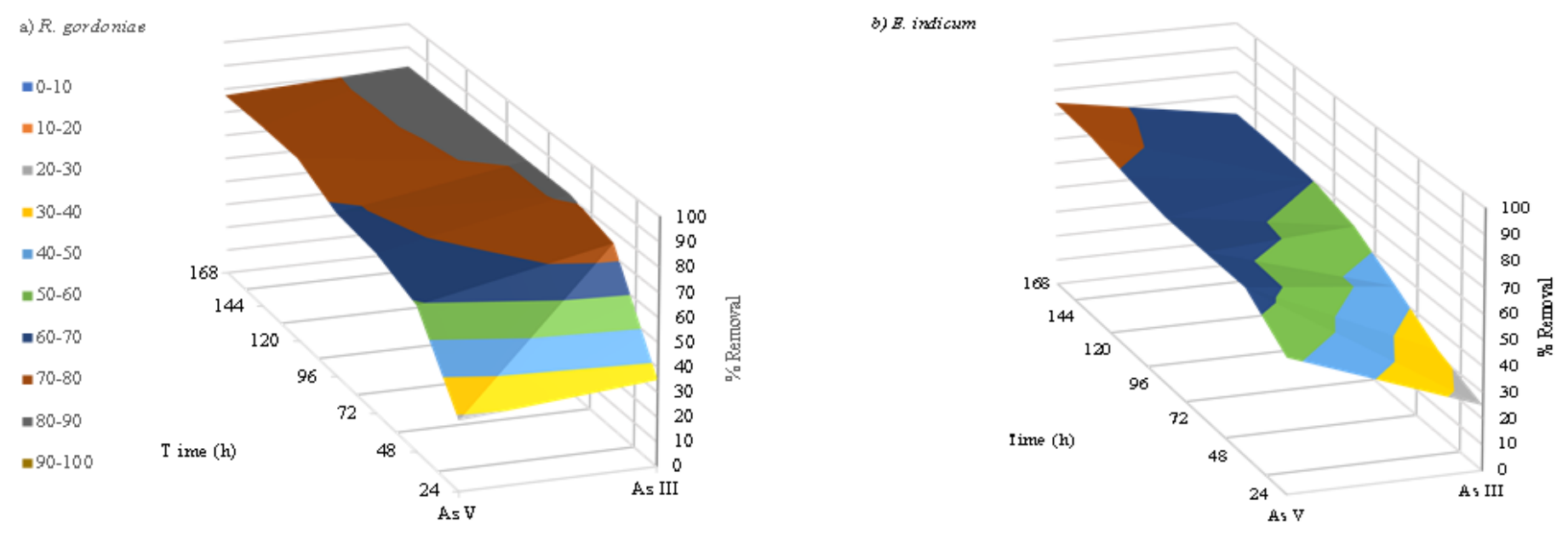

c)M ryctocarionoxycions
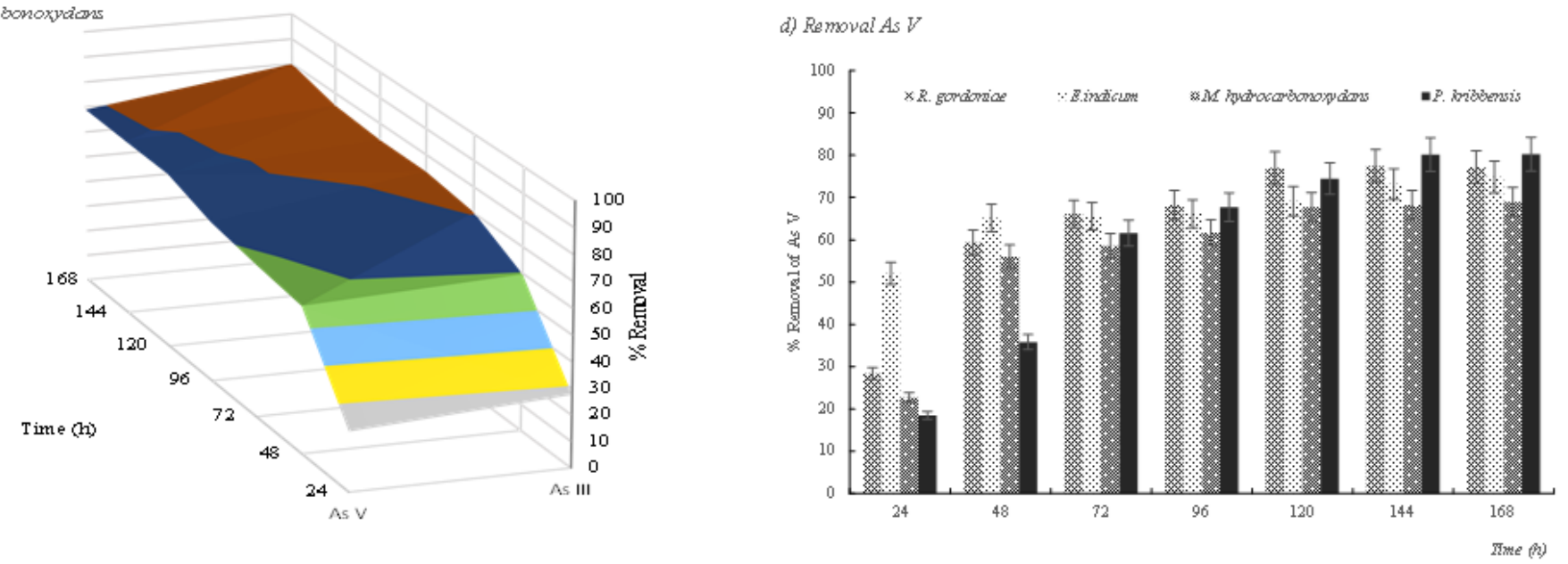

\section{Figure 6}

Graphics of the percentage removal of $\mathrm{As}(\mathrm{III})$ and $\mathrm{As}(\mathrm{V})$ at $24 \mathrm{~h}$ intervals for $168 \mathrm{~h}$. a) R.gordoniae, b) E. indicum, c) M. hydrocarbonoxydans. d) Comparison plot of \% removal for As (V) between P. kribbensis and the other three strains. In P.kribbensis no removal capacity was observed for As (III) at $10 \mathrm{mM}$. For graph d), the error bars indicate the standard error of the triplicate samples. 


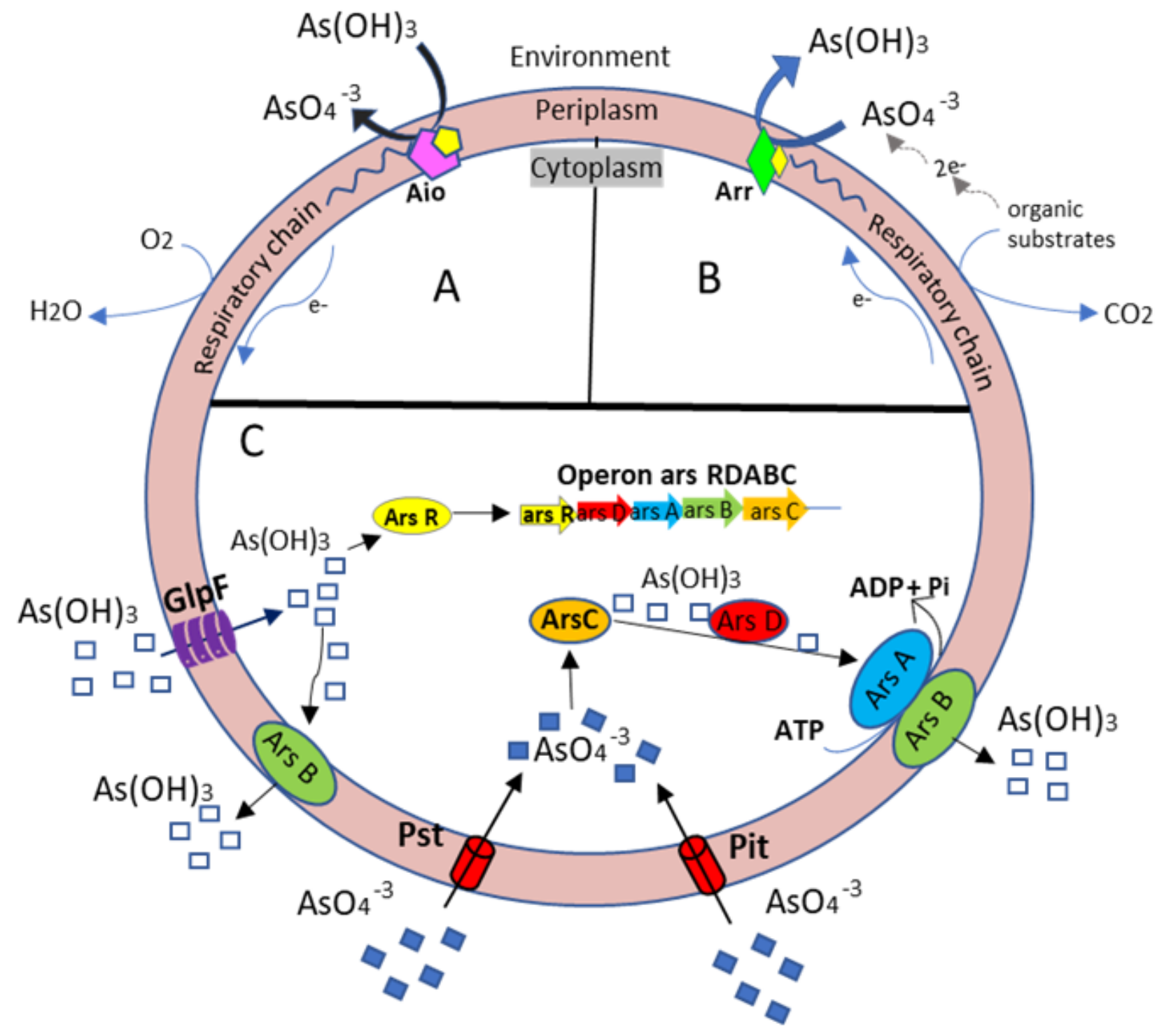

Figure 7

Mechanism of arsenic detoxification in prokaryotic cells. A) Arsenite oxidation: detoxification and energy generation; B) Arsenate reduction: energy generation; C) Mechanism of arsenic resistance: Arsenate (AsO4-3) is taken up by phosphate transporters (Pit and Pst), and arsenite (As(OH)3) is taken up by glycerol facilitator (GlpF). The arsenite binds to the ArsR repressor, inducing expression of the operon arsRDABC, which results in arsenate reduction and arsenite extrusion from the cells. 